\title{
Hormonal and nutritional regulation of postnatal hypothalamic development
}

\author{
Luba Sominsky', Christine L Jasoni², Hannah R Twigg² and Sarah J Spencer ${ }^{1}$ \\ 1School of Health and Biomedical Sciences, RMIT University, Melbourne, Victoria, Australia \\ 2 School of Biomedical Sciences, Centre for Neuroendocrinology, Department of Anatomy, University of Otago, Dunedin, New Zealand \\ Correspondence should be addressed to S J Spencer: Sarah.Spencer@rmit.edu.au
}

\section{Abstract}

The hypothalamus is a key centre for regulation of vital physiological functions, such as appetite, stress responsiveness and reproduction. Development of the different hypothalamic nuclei and its major neuronal populations begins prenatally in both altricial and precocial species, with the fine tuning of neuronal connectivity and attainment of adult function established postnatally and maintained throughout adult life. The perinatal period is highly susceptible to environmental insults that, by disrupting critical developmental processes, can set the tone for the establishment of adult functionality. Here, we review the most recent knowledge regarding the major postnatal milestones in the development of metabolic, stress and reproductive hypothalamic circuitries, in the rodent, with a particular focus on perinatal programming of these circuitries by hormonal and nutritional influences. We also review the evidence for the continuous development of the hypothalamus in the adult brain, through changes in neurogenesis, synaptogenesis and epigenetic modifications. This degree of plasticity has encouraging implications for the ability of the hypothalamus to at least partially reverse the effects of perinatal mal-programming.

\author{
Key Words \\ - metabolism \\ - stress \\ fertility \\ - perinatal \\ - programming
}

\section{The architecture of the hypothalamus}

Neuroanatomically, the adult hypothalamus in humans and rodent models can be sub-divided into anterior, tuberal and posterior, with further subdivisions of each of these depending upon rostrocaudal location and neuronal subtypes present (Pearson \& Placzek 2013, Watts 2015). The various neuronal populations found throughout the hypothalamus are drivers of key biological processes in the mature animal, including feeding and metabolism, stress responsiveness, reproduction, thermoregulation, sleep circadian rhythms and others (Fig. 1). For example, the neuropeptide Y (NPY)/agouti-related protein (AgRP)and pro-opiomelanocortin (POMC)/cocaine- and amphetamine-regulated transcript (CART)- containing neurons of the arcuate nucleus (ARC) respond to circulating satiety hormones, including ghrelin, leptin and insulin to drive (NPY/AgRP; ghrelin) and suppress (POMC/CART; leptin, insulin) feeding (Andermann \& Lowell 2017). The corticotropin-releasing hormone (CRH) and arginine vasopressin (AVP) neurons of the paraventricular nucleus (PVN) respond to stressful stimuli to stimulate release of adrenocorticotropic hormone (ACTH) from the anterior pituitary gland, which subsequently drives the release of corticosterone from the adrenal cortex (Herman et al. 2016). The gonadotropin-releasing hormone (GnRH) neurons of the preoptic area (POA) respond to kisspeptin (Irwig et al. 2004, Han et al. 2005, Messager et al. 2005) and other neuropeptides, such as RFamide-related peptides (Ukena et al. 2002, Ubuka et al. 2009), to regulate 


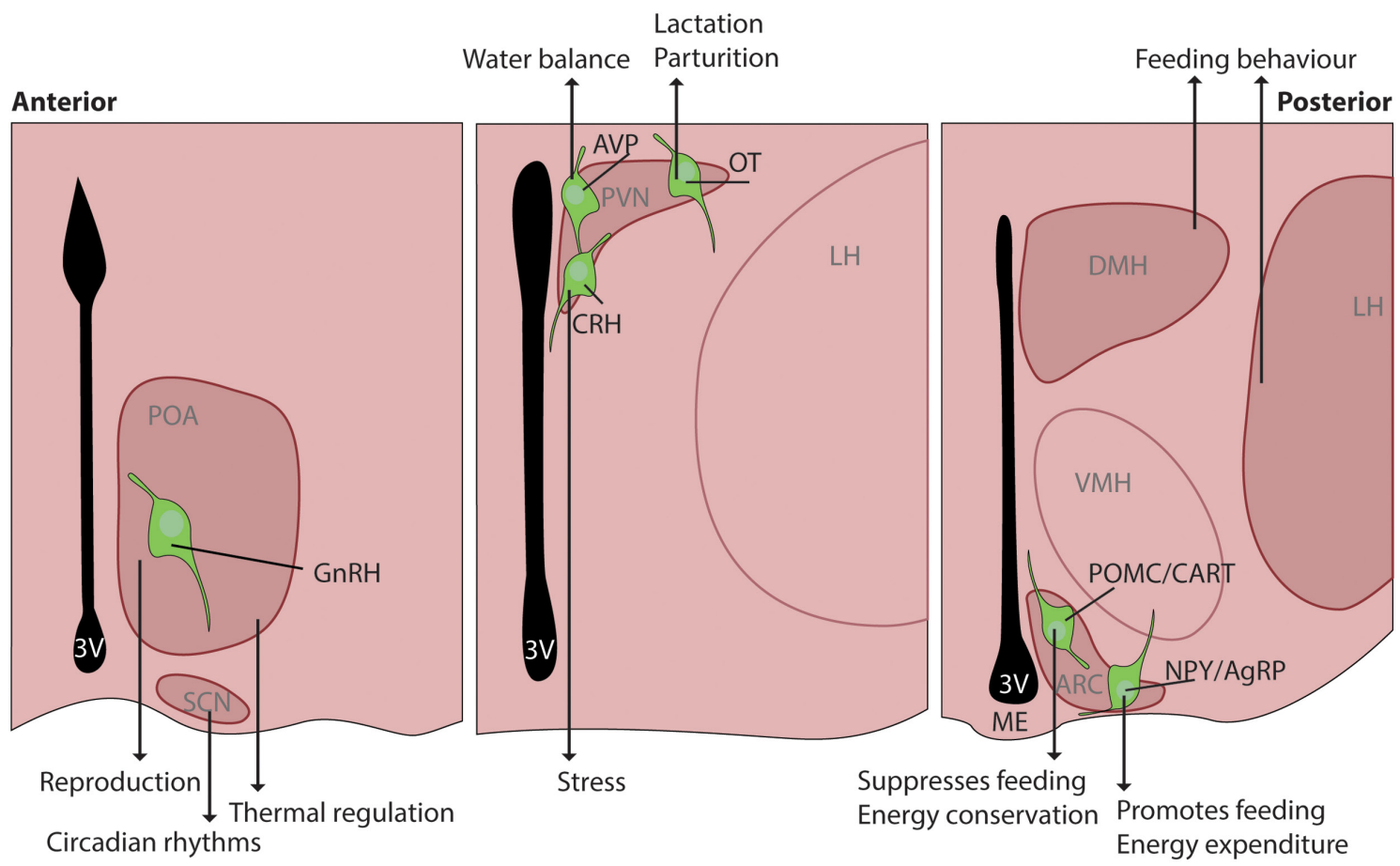

Figure 1

The hypothalamus is a driver of key biological processes in the mature animal, including feeding and metabolism, stress responsiveness and reproductive function. AgRP, agouti-related protein; ARC, arcuate nucleus of the hypothalamus; AVP, arginine vasopressin; CART, cocaine and amphetamine-related transcript; $\mathrm{CRH}$, corticotropin-releasing hormone; $\mathrm{DMH}$, dorsomedial hypothalamus; GnRH, gonadotropin-releasing hormone; $\mathrm{LH}$, lateral hypothalamus; ME, median eminence; NPY, neuropeptide Y; OT, oxytocin; POA, preoptic area; POMC, pro-opiomelancortin; PVN, paraventricular nucleus of the hypothalamus; SCN, suprachiasmatic nucleus; VMH, ventromedial nucleus of the hypothalamus; $3 \mathrm{~V}$, third ventricle.

the pulsatile and tonic release of luteinizing hormone and follicle-stimulating hormone (FSH), which, in females, stimulate ovulation and support ovarian follicle maturation (Krsmanovic et al. 2009, Ohkura et al. 2009). Connections throughout the hypothalamus integrate these functions. For example, NPY/AgRP neurons project to the PVN to convey feeding information to extrahypothalamic brain regions, and this transmission can be curtailed by CRH neurons (Cowley et al. 1999, Lu et al. 2003), facilitating the modulation of food intake by stress. Likewise, kisspeptin fibres originating from the ARC and anteroventral periventricular nucleus (AVPV) can also be found in the PVN and limbic structures (Yeo \& Herbison 2011, Yip et al. 2015) and facilitate modulation of the reproductive axis by stress (Herman et al. 2005).

Establishing the appropriate hypothalamic connectivity is thus essential for an individual's survival, wellbeing and reproduction. It is noteworthy, then, that these circuits are highly vulnerable to early life environmental influences, including by nutritional and hormonal factors, particularly at specific phases of an individual's development (Spencer 2013). However, there are data to suggest that the establishment of this circuitry also displays remarkable resilience in the face of many environmental challenges (e.g. Parker et al. 2005, Macri et al. 2007, Bellisario et al. 2014, Sominsky et al. 2017a,b). In this review, we will discuss the role of hormonal and nutritional regulators of prenatal and postnatal hypothalamic development whose actions shape and define later-life hypothalamic function (Fig. 2).

\section{Prenatal hypothalamic development}

The hypothalamus develops from the rostral/ventral diencephalon from about mid-gestation (gestational day 8.5) in the rodent (Shimamura et al. 1995). The patterning of the neural tube into the developing hypothalamus, as well as early patterning within the hypothalamus has been covered in detail in recent excellent reviews (Bedont et al. 2015, Burbridge et al. 2016, Xie \& Dorsky 2017). Briefly, following early patterning under the influence of Shh, BMPs (dorsoventral) and Wnts (anteroposterior), the hypothalamus can be subdivided into the major regions listed earlier. Each region in turn is then divided into specific nuclei, in a process of 

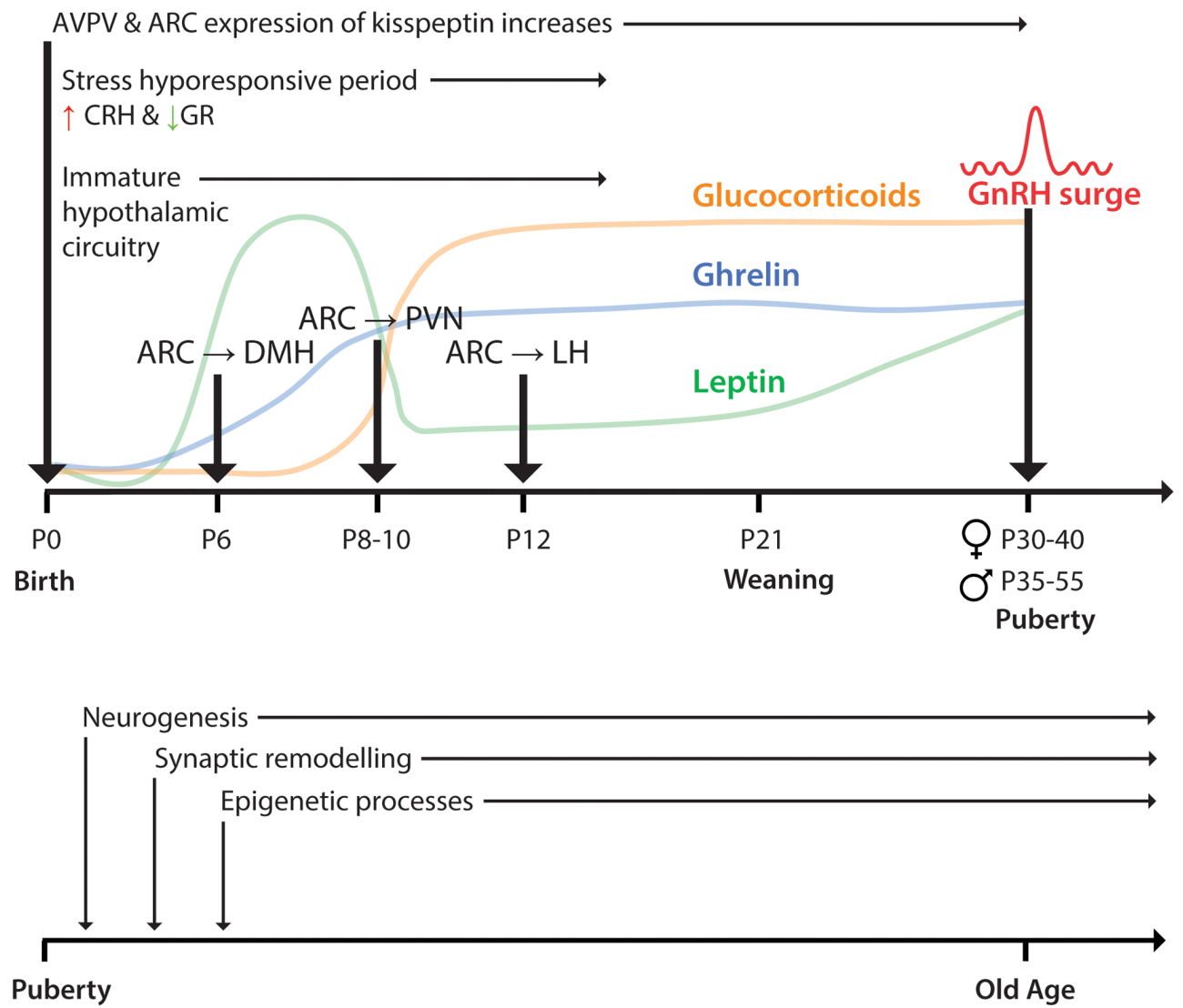

Figure 2

Major milestones of postnatal hypothalamic development in rodents. At birth, hypothalamic neuronal circuitry is a rudimentary scaffold of pioneering axonal projections that are used as guides upon which postnatal projections form and elaborate. A postnatal leptin surge drives the development of neuronal projections from the arcuate nucleus of the hypothalamus (ARC) to dorsomedial hypothalamus (DMH) at postnatal day 6 (P6), to paraventricular nucleus of the hypothalamus (PVN) at P8-10, and to lateral hypothalamus (LH) at P12. A subsequent rise in the levels of ghrelin curbs excessive development of these neuronal connections. The first two weeks of rodent postnatal life are known as a stress hypo-responsive period, associated with low levels of circulating glucocorticoids, increased gene expression of corticotropin-releasing hormone (CRH) and decreased expression of the glucocorticoid receptor (GR). Hypothalamic reproductive circuitry rapidly develops during the first three weeks of life, with continuous increase in the expression of kisspeptin neurons in the anteroventral periventricular nucleus (AVPV) and the ARC, triggering the establishment of GnRH pulsatility. Puberty onset is further triggered by leptin that acts as an indirect permissive signal, particularly in females. Leptin levels increase after weaning, corresponding with the increasing body mass. The development of the hypothalamus does not stop at puberty, but is maintained to some degree throughout life, with continuous changes in neurogenesis, synaptic remodelling and epigenetic modifications. Note, hormonal profiles are indicative only and are not drawn to scale.

ever-finer boundary-forming morphogen gradients that define hypothalamic subdomains or nuclei (Burbridge et al. 2016). Hypothalamic nuclei have been described as being organised in a 'patchwork' (Bedont et al. 2015), mainly because they lack the tidy and obvious lamination exhibited by the neocortex. The molecular origins and functional significance of organisation within the hypothalamus is only just beginning to be understood and will come into clearer focus as hypothalamic lineage relationships are slowly teased apart.

Following initial patterning, subsequent patterns of gene expression act to define the terminally differentiated phenotype of hypothalamic neurons (Campbell et al. 2017). In temporal order of expression, these include genes

$\begin{array}{lr}\text { http://joe.endocrinology-journals.org } & \text { ○ } 2018 \text { Society for Endocrinology } \\ \text { https://doi.org/10.1530/JOE-17-0722 } & \text { Published by Bioscientifica Ltd. } \\ \text { Printed in Great Britain }\end{array}$

that regulate cell type-specific migration (for cells that actively migrate) (see for example: Cariboni et al. 2015, Di Sante et al. 2015, Giacobini 2015, Howard et al. 2016, Hutchins et al. 2016), and axonal and dendritic growth and guidance (see for example: Low et al. 2012, Liao et al. 2015, Sanders et al. 2017). Cell type-specific expression of neurotransmitter/peptides is also a critical developmental step, but this appears to occur at different times across development for different neurons (e.g. GnRH neurons express GnRH prior to and during migration, whereas orexin neurons of the lateral hypothalamus (LH) do not appear to express orexin until situated laterally in the $\mathrm{LH}$ (Twigg 2017, personal observation). As a consequence of this prenatal developmental sequence, by the time of 
birth in the rodent most hypothalamic neurons are in their adult locations, and express the neurotransmitter(s)/ peptide(s) that will define them, and their functions throughout life. In addition, they have extended axons to key target areas and have developed dendrites to synapse with incoming axons. This developmental sequence gives rise to a rudimentary neural circuitry poised to be further elaborated and synaptically sculpted by important environmental factors encountered by the freely living individual after birth. Although we will not cover details of development nor prenatal developmental programming in this review, there is some evidence that metabolic and hormonal perturbation of prenatal development occurs in some of these systems (Chang et al. 2008, Sanders et al. 2014, Moore \& Campbell 2017).

\section{Neonatal hypothalamic development}

\section{Metabolic circuiltry}

Despite this prenatal development of hypothalamic neurons, by the time of birth in rodents the pattern and function of axonal connections throughout the hypothalamus is still immature, particularly in the ARC. The LH melanin-concentrating hormone neurons develop in the embryonic phase (Croizier et al. 2011) and projections between the dorsomedial hypothalamic nucleus (DMH) and the PVN and LH are present and functional before postnatal day 6 (P6) (Bouret et al. 2004a). Projections from the VMH to the forebrain are in place by birth (Cheung et al. 2013). However, axonal projections from the ARC to the DMH are not visible with neuronal tract tracing with DiI until P6 in the mouse. Similarly, ARC to PVN connections are not seen before P8-10, and ARC to LH connections appear at around P12 (Bouret et al. 2004a). As such, DMH neurons are responsive to leptin at P6 but PVN neurons are not (Bouret et al. 2004a).

How such development is restricted to such specific time periods is not clear. Neurodevelopmental genes including $S h h$, a morphogen that regulates neuronal development, are differentially methylated in the ARC compared with PVN, co-incident with the timing of this development (Li et al. 2014), which suggests epigenetic mechanisms are likely to contribute. Receptors for some neurotrophic hormones may also be transiently expressed in developing ARC neurons (Betley et al. 2013). Specific developmental signals also differentially trigger development of different neuronal subtypes. For instance, leptin stimulation of a STAT3-dependent pathway is needed for ARC POMC neuron development, but not for AgRP projections (Bouret et al. 2012).

Once axonal connections are established, synapse formation and maturation takes place. Early electron microscopy studies showed a paucity of synapses in the ARC at birth, with the number increasing from P5 to adulthood (Matsumoto \& Arai 1976). These synapses continue to mature functionally from birth through to adulthood with, for instance, PVN neurons being relatively unresponsive to melanocortin at one week of age but highly responsive in the juvenile phase (Melnick et al. 2007). It is noteworthy that inputs to NPY/AgRP/ GABA neurons in the ARC are predominantly excitatory during the first three weeks of life in the mouse. The switch to inhibitory inputs within this circuitry comes as a result of KATP channel expression and does not occur until around P21 (Juan De Solis et al. 2016).

In 1998, Ahima and colleagues identified a profile of changes in circulating leptin in the neonatal mouse consistent with this hormone performing a neurotrophic function, since at this time neonatal mice are relatively impervious to the anorexigenic effects of leptin (Ahima et al. 1998, Mistry et al. 1999). Thus, leptin levels remain low in neonatal mice and rats until after $\mathrm{P} 4$ at which time they sharply increase over the course of 10-12 days before falling to adult levels (Ahima et al. 1998, Ahima \& Hileman 2000, Delahaye et al. 2008, Cottrell et al. 2009). Bouret and Simerly later expanded on this work to show this leptin surge is responsible for stimulating the development of connections between the ARC and LH (P12), DMH (P6) and PVN (P8-10) in the mouse (Bouret et al. 2004a,b, Bouret \& Simerly 2006). There is further evidence from the Bouret group that ghrelin may similarly act as a trophic signal in the neonatal phase, in this case, with circulating ghrelin concentrations increasing between P10 and P14 and at this point acting to curtail leptinstimulated neurite growth (Steculorum et al. 2015). Insulin is a third hormone important in the development of this circuitry. Although insulin remains relatively constant in early postnatal life, with a gradual increase to adult levels just prior to puberty (Ahima et al. 1998), perturbations in insulin signalling can also influence the development of hypothalamic metabolic circuitry (Plagemann et al. 1992, 1999, Vogt et al. 2014).

\section{Perinatal programming of metabolic circuitry}

The absence of the leptin surge or of functional leptin receptors, and changes to circulating ghrelin and insulin levels, results in suppressed to near-absent neurite 
growth between these regions. These effects can lead to lifelong deficits in satiety and metabolic signalling and pronounced obesity (Bouret et al. 2004b, Steculorum et al. 2015). Ob/ob mice that do not produce leptin are obese compared with controls of the same age and have a substantially reduced density of fibres projecting from the ARC to the PVN and other regions of the hypothalamus (Bouret et al. 2004b). The obese phenotype and the fibre density can be rescued by exogenous leptin given between P4 to P12, but not when leptin is given in adulthood (Bouret et al. 2004b, Vickers et al. 2005, Bouyer \& Simerly 2013). In the mouse, the window within which leptin maintains neurotrophic potential closes around P28, with the duration of the leptin surge likely being important for this development; longer exposures to high leptin having greater neurotrophic potential (Kamitakahara et al. 2018). Early life events that perturb these hormone-based signals can thus have a lasting impact on this hypothalamic circuitry (Table 1 ).

Early life overfeeding, such as by suckling rat and mouse pups in small litters, elevates circulating leptin and also stimulates changes in methylation of the promoter regions for NPY (reduced methylation) and POMC (increased methylation) in the hypothalamus and reduces POMC expression (Lopez et al. 2005, Plagemann et al.
2009, Stefanidis \& Spencer 2012). Neonatal overfeeding also induces acute changes in hypothalamic NPY and AgRP density, and an overweight phenotype that lasts beyond the period of overfeeding (Sominsky et al. 2017b). Similarly, maternal high-fat diet during lactation in mice reduces $\alpha$-melanocyte-stimulating hormone $(\alpha-\mathrm{MSH})$ and AgRP fibre density in the PVN, DMH and LH of the offspring, and this is linked to hyperinsulinemia. Specific inactivation of the insulin receptor in POMC neurons rescues this effect and the negative consequences for glucose tolerance. Speaking to the importance of the postnatal period for this development in rodents, maternal high-fat diet and obesity prior to and during gestation does not alter hypothalamic connectivity in the offspring (Vogt et al. 2014). Likewise, leptin treatments after P28 in the mouse have no effect (Kamitakahara et al. 2018).

Non-nutritive challenges can also influence the hormonal profile during development and stimulate detrimental programming effects on this circuitry. Chronic early life stress is associated with an early reduction in weight gain (P2-P9) followed by a later weight acceleration (P14 onwards) such that the stressed pups have normal weight as adults, but accumulate more adipose when consuming a high-fat diet (Yam et al. 2017a). The effects of early life stress on ghrelin are sex

Table 1 Summary of key studies on perinatal programming of hypothalamic metabolic circuitry.

\begin{tabular}{|c|c|c|}
\hline Model & $\begin{array}{l}\text { Hormonal } \\
\text { correlates }\end{array}$ & Obesity \\
\hline Leptin deficiency - ob/ob & $\downarrow$ leptin & $\checkmark$ \\
\hline Early life stress & $\downarrow$ leptin & $\begin{array}{l}\checkmark \text { transient then } \\
\uparrow \text { adipose with } \\
\text { HFD }\end{array}$ \\
\hline Maternal separation & $\downarrow$ leptin & $\mathrm{X}$ \\
\hline Foetal undernutrition & $\begin{array}{l}\downarrow \text { responses to } \\
\text { leptin }\end{array}$ & $\checkmark$ \\
\hline Neonatal overfeeding & $\uparrow$ leptin & $\checkmark$ \\
\hline Anti-ghrelin & $\downarrow$ ghrelin action & $\checkmark$ \\
\hline Ghrelin & $\uparrow$ ghrelin & $\checkmark$ \\
\hline Insulin implants & $\uparrow$ insulin & $\checkmark$ \\
\hline Maternal HFD - lactation & $\uparrow$ insulin & $\checkmark$ \\
\hline $\begin{array}{l}\text { Maternal HFD prior to and } \\
\text { during gestation (not } \\
\text { lactation) }\end{array}$ & $X$ & $X$ \\
\hline
\end{tabular}

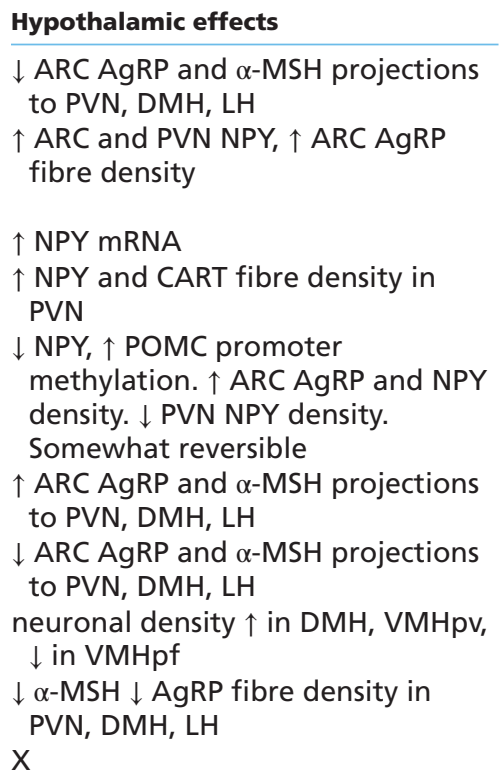

$\alpha-\mathrm{MSH}, \alpha$-melanocyte-stimulating hormone; ARC, arcuate nucleus; AgRP, agouti-related protein; CART, cocaine- and amphetamine-regulated transcript; $\mathrm{DMH}$, dorsomedial hypothalamus; HFD, high-fat diet; LH, lateral hypothalamus; NPY, neuropeptide Y; POMC, pro-opiomelanocrotin; PVN, paraventricular nucleus of the hypothalamus; $\mathrm{VMH}$, ventromedial hypothalamus ( $\mathrm{pv}=$ ventrolateral, $\mathrm{pd}=\mathrm{dorsomedial)}$. 
dependent, suggesting that ghrelin does not influence feeding, metabolic or stress circuitry in this model, since other effects of early life stress on this circuitry are similar between the sexes (Yam et al. 2017b). However, early life stress does lead to a suppression of leptin that may be responsible for some of these long-term weight regulatory effects (Yam et al. 2017a).

While disruptions to weight regulation that ultimately lead to overweight and obesity are seen in early life stress and leptin suppression models, they seem to achieve this via opposing mechanisms to those of hyper-leptinemia. As such, leptin antagonists or leptin receptor polymorphisms prevent neurite growth in the hypothalamus and ultimately reduce the density of axonal projects between the ARC and other regions of the hypothalamus (Bouret et al. 2004b), while leptin suppression with maternal separation is linked to increased hypothalamic NPY mRNA (Schmidt et al. 2006) and leptin suppression with early life stress leads to increased PVN NPY and AgRP fibre density (Yam et al. 2017a,b). A premature leptin surge, as is seen with foetal undernutrition in the mouse, can also lead to increased density of NPY and CART terminals in the PVN, as well as leptin resistance and, again, an obese phenotype into adulthood (Yura et al. 2005). In similar fashion, both hyper- and hypo-ghrelinemia in postnatal life result in an overweight phenotype long term, despite opposite effects on the density of AgRP and $\alpha$-MSH fibres in the PVN (Steculorum et al. 2015). It appears that any perturbation to the hypothalamic metabolic circuitry results, if anything, in an obese phenotype. This effect fits with the idea that maintaining adequate nutrition is a highly essential function for survival there is therefore substantial redundancy towards a drive to eat in this circuitry.

The timing for the development of this hypothalamic feeding circuitry, and its dependence upon leptin and ghrelin, has been relatively well established in the mouse. However, in the rat, the effects of both leptin and ghrelin seem to be less robust and permanent. In neonatally overfed rats, leptin is elevated about 14 -fold in both males and females (Stefanidis \& Spencer 2012); yet, this has only transient or no effects on density of NPY and AgRP fibres in the ARC and PVN. In males, neonatal overfeeding leads to an early increase in NPY/AgRP fibres in the ARC and an early resistance to leptin, both of which are resolved by adulthood although the elevated body weight remains (Sominsky et al. 2017b). Neonatal overfeeding in females has no effect on ARC or PVN AgRP, NPY or POMC and very minimal effects on leptin sensitivity (Ziko et al. 2017). Likewise, neonatal overfeeding affects circulating ghrelin in the male rat, suppressing it rather than increasing it as it does in the mouse. However, its influence on ghrelin sensitivity is only transient, with normal responses to exogenous ghrelin seen in neonatally overfed adults (Sominsky et al. 2017a). It is noteworthy that even in the mouse, body weight and density of ARC axons are normal by P35 in ghrelin knockouts, indicating compensatory factors likely play a role in the case of disruptions to ghrelin signalling in early life (Steculorum et al. 2015).

\section{Equating human and rodent developmental ages}

Much of the literature addressing hypothalamic development comes from rodent (rat and mouse) studies. Although hypothalamic structure and function is highly conserved across species, equating developmental ages between animal models and humans is sometimes problematic and controversial. In the rat and mouse, the cytoarchitecture of the hypothalamus starts to develop at in mid-gestation, with neurogenesis followed by migration, axonal extension, dendritic arborisation and synaptogenesis all commencing prior to birth. There is then a second major developmental phase in the postnatal period, where the satiety and stress circuitry mature between approximately P6 and 16. In humans and nonhuman primates, the relative timing of hypothalamic development is the same, but the absolute timing of different developmental milestones occurs at different times across gestation. For example, the generation of specific cell types begins in the latter part of the first trimester (around 9 weeks) for early generated cells, such as those in the LH, whereas the majority of neurons (those in the POA, DMH, VMH, ARC and PVN) are generated throughout the second trimester (Koutcherov et al. 2002). Subsequent events - migration, axon extension, dendritic arborisation, synaptogenesis and a significant amount of circuit remodelling/elaboration - occur in the third trimester in humans. In rodents, this phase is split such that migration, as well as some axon extension, dendrite formation and synaptogenesis occur before birth and are followed by circuit remodelling and further synaptogenesis in the postnatal period (Koutcherov et al. 2003, Grayson et al. 2006). In terms of later development, the juvenile period in rats and mice is between three and six weeks of age, with puberty occurring around five to six weeks old. Adulthood is thus considered to be from around eight weeks onwards, with reproductive senescence between 15 and 20 months (females) and old age occurring between 24 and 36 months depending on strain (Sengupta 2013). If calculating a linear equivalence in adult rodents based 
on lifespan, one could consider one day in the life of an adult rat to be approximately equivalent to one month in the life of a human (Sengupta 2013). However, this definition is less useful when assessing very short time frames, such as when examining responses to acute stress or satiety signals, and the temporal equivalence of medium-term metabolic challenges is also unclear. These caveats therefore need to be considered when comparing rodent developmental ages to those of humans.

Few studies have investigated the roles of these metabolic factors in human hypothalamic development, but there is evidence that ghrelin is low at birth in humans as it is in mice and rats and that it approximately doubles between birth and one month of age, peaking at the first two years of life and subsiding significantly towards the end of puberty (Soriano-Guillen et al. 2004a). Leptin levels in humans rise during pregnancy and subside after birth in the mother as well as the foetus and newborn, but the magnitude of the increase is not as high as in rodents and a postnatal (or prenatal) leptin surge has not been identified (reviewed in Valleau \& Sullivan 2014). Whether changes to ghrelin and/or leptin in young humans affect the development of hypothalamic circuitry is not clear. Certainly, early weight gain is highly predictive of lifelong obesity (Whitaker et al. 1997, Stettler et al. 2005) and breast milk composition of some of these hormones is linked to rate of weight gain (Kon et al. 2014). There is also some evidence that ghrelin, at least, may correlate with measures of growth at term ( $\geq 37$ weeks' gestation) but not earlier than this (Ng et al. 2005).

\section{Stress circuitry}

In humans, the HPA axis completes its maturation during the last trimester of pregnancy (Bolt et al. 2002). In rats and mice, the critical development of this circuitry occurs postnatally, during the first week of life (reviewed in Rao 2015). At this time, the rat and mouse hypothalamus is characterised by high $\mathrm{Crh}$ gene expression and lower glucocorticoid receptor gene expression that decrease and increase, respectively, as the animal approaches weaning age (Boullu-Ciocca et al. 2005). In this early postnatal phase, the pups are hypo-responsive to stress, having low circulating corticosterone and suppressed ACTH and corticosterone responses to mild psychological stress or immune challenge (Schmidt et al. 2006). This effect is likely one that is maintained by the presence of metabolic factors, including leptin and glucose that are usually obtained through regular suckling from the dam (Schmidt et al. 2006).

\section{Perinatal programming of stress circuitry}

The stress hypo-responsive period in rodents, and, thus, normal maturation of the HPA axis, can be disrupted by changes to metabolic factors. For instance, maternal separation leads to a reduction in pup circulating leptin and glucose, usually obtained from the dam, and an increase in ghrelin. These changes precede the increases in circulating corticosterone and HPA axis activation that signal the termination of the stress hypo-responsive period. Feeding pups during maternal separation can mitigate its effects (Rosenfeld et al. 1993, van Oers et al. 1998). A ghrelin antagonist, as well as replacement glucose, can also restore the corticosterone and ACTH towards their stress hypo-responsive levels (Schmidt et al. 2006). It is likely they do this by influencing the expression of CRH in the PVN, since Crh mRNA is reduced with maternal separation and restored with a ghrelin antagonist or glucose treatment (Schmidt et al. 2006). While no overt effects on weight gain have been reported from maternal separation experiments (and the ensuing reductions in circulating leptin), there is some evidence that satiety and feeding may be disrupted. Maternally separated rats weigh less into adulthood than controls and consume more palatable food. They are also more sensitive to the anorexigenic effects of cholecystokinin (McIntosh et al. 1999). Hypothalamic Npy mRNA is also increased by maternal separation (Schmidt et al. 2006).

Premature termination of the stress hypo-responsive period can lead to a hyper-responsive HPA axis long term. Thus, maternally separated rats have increased immobility in the forced swim (Lajud et al. 2012), elevated basal levels of stress hormones (Rots et al. 1996), and exacerbated anxiety and ACTH responses to a novel environment (Wigger \& Neumann 1999) as adults. Again, these responses are somewhat sex dependent, with both sexes showing increased anxiety but only the males having exacerbated HPA axis responses (Wigger \& Neumann 1999). Early life stress without maternal separation, in experimental animals and in humans, can also lead to exacerbated HPA axis responses to stress later in life. Thus, humans who experience extended periods in institutionalized care, neglect or abuse in early life demonstrate blunting of the normal cortisol rhythm (Gunnar et al. 2001), extremely high or low morning cortisol (Cicchetti \& Rogosch 2001) and exacerbated cortisol responses to stress (Laurent $e t$ al. 2015). This latter effect is predictive of heightened anxiety (Laurent et al. 2015). In rats, chronic early life stress also leads to exacerbated HPA axis responses to stress (Yoshihara \& Yawaka 2008, Yam et al. 2015). This is likely 
due to hypothalamic alterations in CRH and CRFR2, its receptor, expression (Eghbal-Ahmadi et al. 1997, Schmidt et al. 2004) and also to epigenetic modifications to the glucocorticoid and mineralocorticoid receptors in the hypothalamus and elsewhere in the brain. For example, Meaney and colleagues have shown maternal attention suppresses HPA axis responses to stress throughout life via maternal contact-mediated changes in histone acetylation and NGF1-A binding to the glucocorticoid receptor promoter to increase expression of this receptor and enhance the efficiency of glucocorticoid-negative feedback (Weaver et al. 2004a).

Neonatal overfeeding can also interrupt normal HPA axis development, prematurely elevating circulating glucocorticoids, ACTH and hypothalamic glucocorticoid receptor expression, as well as reducing hypothalamic $\mathrm{Crh}$ mRNA (Boullu-Ciocca et al. 2005). These effects are linked to exacerbated HPA axis responses to immune challenge long term in both males and females that were overfed as neonates (Clarke et al. 2012), and exacerbated responses to psychological stress in females (Spencer \& Tilbrook 2009).

\section{Reproductive circuitry}

Central reproductive circuitry is established predominantly prenatally (reviewed in Franceschini \& Desroziers 2013), but substantial changes in the expression and function of this circuitry occur postnatally, particularly during the peripubertal period, since activation of the GnRH neurons is critical for the initiation of puberty (Plant \& Barker-Gibb 2004). This activation is thought to be driven by kisspeptin neurons within the hypothalamus that are central to the onset and progression of puberty (Terasawa et al. 2013).

In rodents, expression of kisspeptin neurons in the AVPV increases dramatically postnatally (Navarro et al. 2004, Han et al. 2005). In rats, no kisspeptin neurons are detected in the AVPV at P10. However, by the initiation of puberty, their expression rapidly reaches adult-like levels, in both sexes, accompanied by the development of kisspeptin projections to GnRH neurons (Clarkson \& Herbison 2006). These postnatal changes in kisspeptin expression within the AVPV are dependent upon the increasing levels of estradiol (Clarkson et al. 2009, Takase et al. 2009). There is thus a substantial sex difference in the expression of kisspeptin neurons, with females expressing significantly more of these in the AVPV in mice (Clarkson \& Herbison 2006) and in the AVPV and ARC in rats (Takumi et al. 2011) than males. This sex difference is particularly significant given that the population of kisspeptin neurons in this region sends direct projections to GnRH neuronal cell bodies in the POA (Yip et al. 2015). These postnatal temporal and spatial changes in the expression of kisspeptin suggest that pubertal development is initiated by the population of ARC kisspeptin neurons and is followed by an estradiol-dependent activation of AVPV kisspeptin neurons triggering the GnRH release.

As with rodents, in non-human primates, the hypothalamic content of kisspeptin and its receptor increase in the prepubertal period (Shahab et al. 2005, Keen et al. 2008). This pattern occurs in parallel to the peripubertal increase in GnRH release (Watanabe \& Terasawa 1989). This pubertal increase in kisspeptin signalling is, however, independent of the concomitant increase in circulating estradiol in primates, and is not likely to drive increased pubertal GnRH release but rather mediates the reduction in GABA inhibition of GnRH neurons (Guerriero et al. 2012, Kurian et al. 2012). In primates, GnRH pulsatility is increased after birth and this is followed by a decline in late infancy and during juvenile development, maintaining gonadal quiescence until the onset of puberty (Plant \& Witchel 2006, Terasawa \& Kurian 2012). This suppression of GnRH release is mediated by an inhibitory GABAergic tone, and the reduction of GABA inhibition reactivates GnRH pulsatility and triggers puberty (Terasawa 2005). In contrast to primates, postnatal GnRH release in rodents is negligible and its levels increase prior to puberty, likely reflective of the final stages of maturation of the GnRH circuitry rather than the reactivation of the prenatally established circuitry that occurs in primates (Plant 2015).

\section{Perinatal programming of reproductive circuitry}

Pubertal maturation in all species is highly dependent on the ability of an organism to maintain adequate energy balance and varying metabolic conditions play pivotal role in determining the timing of puberty onset (Sanchez-Garrido \& Tena-Sempere 2013). Therefore, poor dietary conditions during gestation and/or postnatal development that alter the development of metabolic circuitry and change the availability of circulating metabolic hormones have also been shown to not only change the timing of puberty but, at times, to program long-term alterations in hypothalamic reproductive functionality. Of the major metabolic hormones, leptin and ghrelin have received significant attention as primary candidates linking metabolic status and hypothalamic reproductive signalling. 
Leptin has long been recognised as a major permissive signal for the onset of puberty, especially in females (Cheung et al. 1997). Ob/ob mice do not undergo puberty and are infertile and a normal phenotype is restored by chronic leptin treatment (Barash et al. 1996, Chehab et al. 1996). Similarly, in human patients with congenital leptin deficiency, pubertal development is restored by leptin treatment (Farooqi et al. 1999, 2002). Leptin also promotes pubertal development in normal rats and mice (Ahima et al. 1997, Chehab et al. 1997, Cheung et al. 1997), and leptin levels are inversely correlated with the age at menarche in pubertal girls (Matkovic et al. 1997).

Leptin's actions on GnRH pulsatility leading to puberty onset are indirect. Immunohistochemical analyses of the mouse and sheep brain have confirmed that while there are populations of leptin receptor expressing neurons in the ventral premammilary nucleus of the hypothalamus and POA, leptin receptor is not expressed by $\mathrm{GnRH}$ neurons nor by AVPV kisspeptin neurons (Louis et al. 2011). Leptin thus stimulates a distinct population of Ob-Rb-expressing neurons in the ventral premammilary nucleus of the hypothalamus to induce $\mathrm{GnRH}$ release from the POA (Donato et al. 2011).

Ghrelin's actions on GnRH/luteinising hormone release and puberty onset are predominantly inhibitory, and males appear to be more susceptible to this inhibitory effect of ghrelin pre-puberty than females (FernandezFernandez et al. 2004, 2005, 2007, Martini et al. 2006). Fasting, as well as acute ghrelin administration, significantly reduce Kiss 1 mRNA expression in the POA (Forbes et al. 2009). However, there is no evidence for the expression of the ghrelin receptor (growth hormone secretagogue receptor, GHSR) on GnRH, kisspeptin or RFamide-related peptide neurons (Smith et al. 2013). The vast majority of hypothalamic GHSR-expressing neurons express estrogen receptor (ER) $\alpha$, suggesting the inhibitory action of ghrelin on GnRH release is likely to be mediated by estradiol (Smith et al. 2013, Frazao et al. 2014). In humans, circulating ghrelin is significantly increased in early childhood and these levels then subside by puberty (Whatmore et al. 2003, Soriano-Guillen et al. 2004b). The influence of the pre-pubertal decline in ghrelin on earlier puberty onset is particularly pronounced in boys (Whatmore et al. 2003), suggesting that under normal conditions, the falling ghrelin levels during the peripubertal period may act as a permissive metabolic signal on puberty, while under pathological conditions, such as in boys with constitutional delay of growth and puberty, ghrelin levels are significantly increased and are negatively correlated with measures of body weight and height (El-Eshmawy et al. 2010, Sen et al. 2010).

Regardless of the mode of leptin and ghrelin's actions on the hypothalamic GnRH pulse generator, multiple studies have demonstrated that perinatal diet alters the timing of puberty onset and impairs ovulation in the offspring, indicating a dysregulation of the hypothalamic reproductive circuitry. In children, excess adiposity in early childhood in girls is typically linked to advanced puberty, while pubertal development in obese boys appears to be delayed. Childhood obesity in both sexes, however, predisposes to significant reproductive dysfunction in adulthood (reviewed in Burt Solorzano \& McCartney 2010). A tendency for earlier pubarche has also been identified in girls born to mothers who were obese and/or suffered from gestational diabetes mellitus (Kubo et al. 2016). In rats, consumption of high-fat diet during pregnancy and lactation is associated with the advancement of puberty and irregular oestrous cyclicity in adult female offspring, indicative of early reproductive senescence (Sloboda et al. 2009, Connor et al. 2012). Early life overfeeding is also associated with increased postnatal body weight and earlier age at vaginal opening in rats and mice (Caron et al. 2012, Smith \& Spencer 2012), along with a persistent increase in the levels of leptin (Castellano et al. 2011, Sominsky et al. 2016) and a significant decline in circulating ghrelin pre-puberty (Collden et al. 2015). A pubertal increase in the hypothalamic expression of kisspeptin has also been shown in the neonatally overfed in one (Castellano et al. 2011), but not other studies (Caron et al. 2012, Smith \& Spencer 2012), possibly due to differences in the timing of observations. In contrast, neonatally overfed females have a reduction in prepubertal ARC-derived kisspeptin fibres (Caron et al. 2012).

Insufficient energy reserve and calorie restriction pre- and postnatally are also known to produce longterm negative effects on hypothalamically-mediated pubertal development and adult reproductive function. The onset of puberty is typically delayed in males and females that experienced maternal undernutrition or intrauterine growth restriction (Engelbregt et al. 2000, Rae et al. 2002, Leonhardt et al. 2003, Guzman et al. 2006). Despite rapid postnatal catch-up growth and significantly increased circulating leptin levels, female offspring of undernourished dams show decreased hypothalamic expression of Kiss1 mRNA that may contribute to delayed puberty (Iwasa et al. 2010). Similarly, postnatal undernutrition delays pubertal development (Caron et al. 2012, Smith \& Spencer 2012). While the delay in puberty onset in undernourished males has been associated with 
changes in circulating testosterone and estradiol, but not with hypothalamic Kiss1 mRNA expression (Smith \& Spencer 2012), neonatally underfed females show impaired development of axonal projections from the ARC to the POA pre-puberty, leading to a reduction in the density of kisspeptin fibres in the POA that is maintained into adulthood (Caron et al. 2012). Both undernutrition and overfeeding during the first three weeks of postnatal life lead to reduced reproductive performance in adulthood, with fewer litters being born to these mice than in controls (Caron et al. 2012).

Poor maternal care and increased perinatal stress similarly predict changes in the timing of puberty onset in the offspring. Michael Meaney's group has shown that prenatal stress induced by low-quality maternal care predicts early puberty onset, but, interestingly, also higher sexual receptivity and increased fecundity. In adulthood, these female offspring also have increased proestrous levels of luteinizing hormone and progesterone, and these changes are likely mediated by the increased expression of ER $\alpha$ in the AVPV (Cameron et al. 2008). These data highlight the potential adaptation of reproductive strategies to environmental conditions. Since limited allocation of parental care is likely to be reflective of limited resources, advanced reproductive development and increased motivation to mate aim to compensate for the higher risk of mortality and thus favour increased quantity of offspring, rather than optimal quality (Cameron 2011).

\section{Adult hypothalamic development}

The prenatal, early postnatal and pubertal periods are important phases for hypothalamic development that are particularly vulnerable to environmental influence. However, it is now clear that the hypothalamus, and, indeed, the brain as a whole, continues to change throughout life and into old age. In addition to the two canonical sites of adult neurogenesis, the hippocampal subgranular zone and the subventricular zone of the lateral ventricle, several other regions throughout the brain, including hypothalamus, are now known to display neurogenesis and gliogenesis in response to specific stimuli (Migaud et al. 2016). Hypothalamic tanycytes that line the base of the third ventricle at the median eminence are a key neurogenic population that give rise to functional neurons throughout early postnatal and adult life (Lee et al. 2012) and into old age (Chaker et al. 2016). Evidence suggests that new hypothalamic neurons both respond to and regulate key hypothalamic functions including satiety and energy balance, stress responses and reproduction. For instance, inhibition of neural stem cell proliferation or ablation of neural stem cells leads to changes in weight gain and energy expenditure in the mouse and chronic high-fat diet can affect neural stem cell survival and rate of proliferation (Lee et al. 2012, Li et al. 2012). Whether neural stem cell proliferation is enhanced or suppressed by high-fat diet and whether this contributes to weight gain or loss is, however, yet unclear as studies have illustrated changes in both directions and with some sex dependency (Lee et al. 2012, Li et al. 2012, Blackshaw et al. 2016). As with neurons involved in metabolic function, those involved in the reproductive circuitry also continue to be produced throughout life, even in older animals (mice of 16 months) (Chaker et al. 2016). Furthermore, inhibiting cell proliferation in this region can suppress the luteinizing hormone surge necessary to stimulate ovulation (Mohr et al. 2017). Adult hypothalamic neurogenesis is regulated by insulin-like growth factors (IGF) and other circulating hormones (Bless et al. 2014, Chaker et al. 2016), with conditional ablation of the IGF receptor from hypothalamic stem cells elevating neuronal production (Chaker et al. 2016). Thus, environmental stimuli that influence neurogenesis can continue to contribute to hypothalamic development throughout life.

The adult hypothalamus is also subject to environmental influence guiding synaptogenesis. For instance, in the rat and primate brain, there is a reversible loss of up to $50 \%$ of axosomatic synapses in the ARC that precedes the preovulatory luteinizing hormone surge each cycle, and this loss is reversed by the morning of metestrous (Olmos et al. 1989, Witkin et al. 1991, Zsarnovszky et al. 2001). This synaptic remodelling is regulated by cyclical fluctuations in estradiol, since estradiol immunoneutralisation prevents synaptic retraction in the ARC, blocks the positive feedback of estradiol and prevents the ovulatory luteinizing hormone surge (Naftolin et al. 1996). The fluctuating levels of IGF1 in the ARC are also implicated in estradiol-induced synaptic remodelling, and IGF1 receptor activation appears to be necessary for the synaptic plasticity seen during the estrous cycle (Fernandez-Galaz et al. 1999). During aging, female rodents lose this synaptic plasticity in the ARC and cease to respond to the mid-cycle estrogen-induced gonadotropin surge, entering constant vaginal oestrous. These effects are mimicked by ovariectomy and can be reversed by estradiol supplementation (Hung et al. 2003). Similar to estadiol, leptin regulates hypothalamic synaptic plasticity and both 
estradiol and leptin remodel the excitatory synaptic input to POMC neurons in the ARC. While estradiol's effects on POMC neurons are independent of leptin and its receptor (Gao et al. 2007), estradiol activates a STAT3-dependent pathway (Bjornstrom \& Sjoberg 2002) and increases leptin-induced STAT3 phosphorylation in the ARC (Clegg et al. 2006), implicating the STAT3 pathway in estradiolinduced synaptogenesis. Independently, exogenous leptin can restore the deficits in numbers of synapses onto NPY and POMC cells in ob/ob mice, also restoring the balance between excitatory and inhibitory synapses and the functional activity of these neurons (Pinto et al. 2004). Exogenous ghrelin has a similar ability to cause dynamic changes in hypothalamic synaptic density and function, in this case, decreasing excitatory and inhibitory synaptic inputs onto POMC cells in an effect consistent with ghrelin's orexigenic function (Pinto et al. 2004). At least in the case of leptin, this effect may be mediated by increases in the expression of brain-derived neurotrophic factor (Komori et al. 2006). These findings suggest leptin and ghrelin may modulate synaptogenesis in accordance with metabolic need, at least in larger doses under pathological conditions (ob/ob mice). Whether dietary manipulations can acutely drive these effects in healthy animals remains to be seen. However, long-term diet-induced obesity in adult mice leads to synaptic attrition in those vulnerable to the obesity-inducing effects of the diet, as well as a failure to increase inhibitory synapses such as is seen in obesity-resistant individuals (Horvath et al. 2010).

In additional to hypothalamic neurogenesis and synaptogenesis, environmental stimuli can also influence the epigenome. It has been identified for some time that significant life stress, including war trauma, or abuse, even in adulthood, can lead to changes in methylation of the promoter for the glucocorticoid receptor. The majority of human studies on this topic have relied upon blood or saliva to assess epigenetic changes in hypothalamic-relevant genes. Thus, there is a link between epigenetic changes to salivary glucocorticoid receptor and memory dysfunction in post-traumatic stress disorder (PTSD). Male survivors of genocidal war with higher glucocorticoid receptor promoter DNA methylation report fewer instances of intrusive memories (Vukojevic et al. 2014). As such, reduced methylation at the glucocorticoid receptor promoter is likely to account for higher expression of the receptor and a vulnerability to PTSD (Yehuda et al. 2015). Meaney and colleagues have shown this mechanism is important centrally with methylation at $\mathrm{Ngf1a}$ affecting transcription of the glucocorticoid receptor and thus HPA axis reactivity at the level of the hippocampus as a consequence of variations in maternal attention (Weaver et al. 2004a,b). While these studies focussed on the hippocampus, methylation at the level of the hypothalamus also appears important for regulating transcription of the glucocorticoid receptor in this region, at least in that promoter $1_{7}$ methylation levels are inversely correlated with glucocorticoid receptor transcription. However, chronic stress has no effect on PVN methylation or glucocorticoid receptor expression, despite effects at pituitary and adrenal (Witzmann et al. 2012). Thus, DNA methylation patterns are variable and vulnerable to challenge throughout life, but more work is needed to elucidate specific hypothalamic effects.

\section{Conclusions}

The hypothalamus plays a major role in the homeostatic control of metabolism, stress responsiveness, central reproductive function, as well as in thermoregulation, sleep and other biological processes. While several structural and functional components of the hypothalamic neuronal network are laid down prenatally, these circuitries undergo further extensive development and fine tuning postnatally. As such, the establishment of the metabolic circuitry is guided by the fluctuation in major metabolic hormones, leptin and ghrelin; the maturation of the stress hypothalamic circuitry is driven by the rise in circulating glucocorticoids; and, AVPV and ARC reproductive circuitry change rapidly postnatally, to attain their adult functionality at puberty, which, in females, is marked by the establishment of pulsatile pattern of GnRH release. Considering the functional and anatomical interconnections among these networks, it may not be surprising that similar environmental influences can trigger changes in their establishment and functionality. As such, alterations in the levels of metabolic, stress and reproductive hormones, or varied nutritional supply during early development, may change the normal developmental trajectory of the hypothalamus, altering the developing, and, consequently, the adult brain. Although the perinatal period of life is undoubtedly the most vulnerable to environmental influences, the adult brain is not protected from harm, with exposure to poor diet or extreme stress inducing significant changes in hypothalamic neuronal connectivity, through changes in neurogenesis and the epigenome. Hypothalamic synaptic plasticity, significantly pronounced in the female brain, is highly dependent on the exposure to sex steroids and is thus lost at reproductive senescence, inducing further 
changes in the central control of energy balance and adiposity.

The development of the hypothalamus throughout life is sex specific to a degree. There does not appear to be sexual dimorphism in the timing of hypothalamic development (Kamitakahara et al. 2018). However, sensitivity to environmental effects may differ between males and females. Thus, female ob/ob mice are more responsive than males to the restorative effects of leptin on AgRP innervation of the hypothalamus (Kamitakahara et al. 2018). Unlike males, female rats are also not susceptible to the hypothalamic re-organisation effects of neonatal overfeeding (Ziko et al. 2017), suggesting a degree of resilience in this sex. This effect is likely related to sex differences in sensitivity to gonadal hormones, since ARC neurons express androgen receptors and ER $\alpha$ at these early ages (Kamitakahara et al. 2018) and hypothalamic neurons are sensitive to exposure to sex steroids in the first weeks of life (Waters \& Simerly 2009). There are also evident species differences in hypothalamic development. Humans, for instance, may not have a developmental leptin surge as rodents do (Valleau \& Sullivan 2014). Rats and mice both display a leptin surge that is important for establishing metabolic hypothalalmic connectivity (Ahima et al. 1998, Delahaye et al. 2008) and both display similar temporal changes in hormones and gene expression relevant for stress and reproductive circuitry (Walker et al. 1997, Boullu-Ciocca et al. 2005, Castellano et al. 2011, Caron et al. 2012). However, while perturbations in leptin and ghrelin during development can permanently disrupt hypothalamic connections and weight regulation in mice (e.g. (Bouret et al. 2004b, Steculorum et al. 2015), the effects are somewhat reversible in rats (Sominsky et al. $2017 a, b)$, suggesting compensatory mechanisms may be at play.

Despite sex and species, though, it is important to remember that this continuous plasticity of the brain, including the hypothalamus, holds a unique key to our ability to improve or reverse the negative influences we have experienced throughout our life. For instance, lifestyle changes, such as exercise and weight loss, are showing promising effects in improving hypothalamic metabolic function in the obese (Laing et al. 2016). Similarly, weight loss appears to be beneficial for obese women who suffer infertility and hypothalamic amenorrhea (Clark et al. 1995), and enriched environment in adolescence has been shown to reverse the effects of prenatal stress by normalising HPA axis stress reactivity (Morley-Fletcher et al. 2003). Our own findings show that changes in the development of hypothalamic metabolic connectivity induced by postnatal overfeeding in rats are resolved by adulthood, when animals are placed on a normal chow diet (Sominsky et al. 2017b). Overall, these encouraging data suggest that while severe disruption of hypothalamic development has detrimental consequences on a range of biological processes, milder influences may have a transient effect that at times can be reversed.

\section{Declaration of interest}

The authors declare that they have no conflict of interest that could be perceived as prejudicing the impartiality of this review.

\section{Funding}

This work was supported by funding from an RMIT University Vice Chancellor's Fellowship to L Sominsky, Health Research Council (New Zealand) and Marsden Fund grants to C Jasoni, a University of Otago Doctoral Fellowship to $\mathrm{H}$ Twigg, and by an Australian National Health and Medical Research Council Career Development Fellowship and a Brain Foundation Research Gift to S J Spencer.

\section{References}

Ahima RS \& Hileman SM 2000 Postnatal regulation of hypothalamic neuropeptide expression by leptin: implications for energy balance and body weight regulation. Regulatory Peptides 92 1-7. (https://doi. org/10.1016/S0167-0115(00)00142-7)

Ahima RS, Dushay J, Flier SN, Prabakaran D \& Flier JS 1997 Leptin accelerates the onset of puberty in normal female mice. Journal of Clinical Investigation 99 391-395. (https://doi.org/10.1172/JCI119172)

Ahima RS, Prabakaran D \& Flier JS 1998 Postnatal leptin surge and regulation of circadian rhythm of leptin by feeding. Implications for energy homeostasis and neuroendocrine function. Journal of Clinical Investigation 101 1020-1027. (https://doi.org/10.1172/JCI1176)

Andermann ML \& Lowell BB 2017 Toward a wiring diagram understanding of appetite control. Neuron 95 757-778. (https://doi. org/10.1016/j.neuron.2017.06.014)

Barash IA, Cheung CC, Weigle DS, Ren H, Kabigting EB, Kuijper JL, Clifton DK \& Steiner RA 1996 Leptin is a metabolic signal to the reproductive system. Endocrinology 137 3144-3147. (https://doi. org/10.1210/endo.137.7.8770941)

Bedont JL, Newman EA \& Blackshaw S 2015 Patterning, specification, and differentiation in the developing hypothalamus. Wiley Interdisciplinary Reviews Developmental Biology 4 445-468. (https://doi.org/10.1002/ wdev.187)

Bellisario V, Berry A, Capoccia S, Raggi C, Panetta P, Branchi I, Piccaro G, Giorgio M, Pelicci PG \& Cirulli F 2014 Gender-dependent resiliency to stressful and metabolic challenges following prenatal exposure to high-fat diet in the p66(Shc-/-) mouse. Frontiers in Behavioral Neuroscience 8 285. (https://doi.org/10.3389/fnbeh.2014.00285)

Betley JN, Cao ZF, Ritola KD \& Sternson SM 2013 Parallel, redundant circuit organization for homeostatic control of feeding behavior. Cell 155 1337-1350. (https://doi.org/10.1016/j.cell.2013.11.002)

Bjornstrom L \& Sjoberg M 2002 Signal transducers and activators of transcription as downstream targets of nongenomic estrogen receptor actions. Molecular Endocrinology 16 2202-2214. (https://doi. org/10.1210/me.2002-0072)

Blackshaw S, Lee DA, Pak T \& Yoo S 2016 Regulation of body weight and metabolism by tanycyte-derived neurogenesis in young adult 
mice. In Stem Cells in Neuroendocrinology, Eds D Pfaff \& Y Christen. Cham, Switzerland: Springer. (https://doi.org/10.1007/978-3-31941603-8_5)

Bless EP, Reddy T, Acharya KD, Beltz BS \& Tetel MJ 2014 Oestradiol and diet modulate energy homeostasis and hypothalamic neurogenesis in the adult female mouse. Journal of Neuroendocrinology 26 805-816. (https://doi.org/10.1111/jne.12206)

Bolt RJ, van Weissenbruch MM, Lafeber HN \& Delemarre-van de Waal HA 2002 Development of the hypothalamic-pituitary-adrenal axis in the fetus and preterm infant. Journal of Pediatric Endocrinology and Metabolism 15 759-769.

Boullu-Ciocca S, Dutour A, Guillaume V, Achard V, Oliver C \& Grino M 2005 Postnatal diet-induced obesity in rats upregulates systemic and adipose tissue glucocorticoid metabolism during development and in adulthood: its relationship with the metabolic syndrome. Diabetes $\mathbf{5 4}$ 197-203. (https://doi.org/10.2337/diabetes.54.1.197)

Bouret SG \& Simerly RB 2006 Developmental programming of hypothalamic feeding circuits. Clinical Genetics 70 295-301. (https:// doi.org/10.1111/j.1399-0004.2006.00684.x)

Bouret SG, Draper SJ \& Simerly RB 2004a Formation of projection pathways from the arcuate nucleus of the hypothalamus to hypothalamic regions implicated in the neural control of feeding behavior in mice. Journal of Neuroscience 24 2797-2805. (https://doi. org/10.1523/JNEUROSCI.5369-03.2004)

Bouret SG, Draper SJ \& Simerly RB $2004 b$ Trophic action of leptin on hypothalamic neurons that regulate feeding. Science 304 108-110. (https://doi.org/10.1126/science.1095004)

Bouret SG, Bates SH, Chen S, Myers MG Jr\& Simerly RB 2012 Distinct roles for specific leptin receptor signals in the development of hypothalamic feeding circuits. Journal of Neuroscience 32 1244-1252. (https://doi.org/10.1523/JNEUROSCI.2277-11.2012)

Bouyer K \& Simerly RB 2013 Neonatal leptin exposure specifies innervation of presympathetic hypothalamic neurons and improves the metabolic status of leptin-deficient mice. Journal of Neuroscience 33 840-851. (https://doi.org/10.1523/JNEUROSCI.3215-12.2013)

Bruce J, Fisher PA, Pears KC \& Levine S 2009 Morning cortisol Levels in preschool-aged foster children: differential effects of maltreatment type. Developmental Psychobiology 51 14-23. (https://doi.org/10.1002/ dev.20333)

Burbridge S, Stewart I \& Placzek M 2016 Development of the neuroendocrine hypothalamus. Comprehensive Physiology 6 623-643.

Burt Solorzano CM \& McCartney CR 2010 Obesity and the pubertal transition in girls and boys. Reproduction 140 399-410. (https://doi. org/10.1530/REP-10-0119)

Cameron NM 2011 Maternal programming of reproductive function and behavior in the female rat. Frontiers in Evolutionary Neuroscience 310. (https://doi.org/10.3389/fnevo.2011.00010)

Cameron N, Del Corpo A, Diorio J, McAllister K, Sharma S \& Meaney MJ 2008 Maternal programming of sexual behavior and hypothalamicpituitary-gonadal function in the female rat. PLOS ONE 3 e2210. (https://doi.org/10.1371/journal.pone.0002210)

Campbell JN, Macosko EZ, Fenselau H, Pers TH, Lyubetskaya A, Tenen D, Goldman M, Verstegen AM, Resch JM, McCarroll SA, et al. 2017 A molecular census of arcuate hypothalamus and median eminence cell types. Nature Neuroscience 20 484-496. (https://doi.org/10.1038/ nn.4495)

Cariboni A, Valentina A, Davidson K \& Parnavelas J 2015 The molecular control of GnRH neuron development. Springerplus 4 L46. (https:// doi.org/10.1186/2193-1801-4-S1-L46)

Caron E, Ciofi P, Prevot V \& Bouret SG 2012 Alteration in neonatal nutrition causes perturbations in hypothalamic neural circuits controlling reproductive function. Journal of Neuroscience 32 11486-11494. (https://doi.org/10.1523/JNEUROSCI.6074-11.2012)

Castellano JM, Bentsen AH, Sánchez-Garrido MA, Ruiz-Pino F, Romero M, Garcia-Galiano D, Aguilar E, Pinilla L, Diéguez C, Mikkelsen JD \& Tena-Sempere M 2011 Early metabolic programming of puberty onset: impact of changes in postnatal feeding and rearing conditions on the timing of puberty and development of the hypothalamic kisspeptin system. Endocrinology 152 3396-3408. (https://doi.org/10.1210/ en.2010-1415)

Chaker Z, George C, Petrovska M, Caron JB, Lacube P, Caillé I \& Holzenberger M 2016 Hypothalamic neurogenesis persists in the aging brain and is controlled by energy-sensing IGF-I pathway. Neurobiology of Aging 41 64-72. (https://doi.org/10.1016/j. neurobiolaging.2016.02.008)

Chang GQ, Gaysinskaya V, Karatayev O \& Leibowitz SF 2008 Maternal high-fat diet and fetal programming: increased proliferation of hypothalamic peptide-producing neurons that increase risk for overeating and obesity. Journal of Neuroscience 28 12107-12119. (https://doi.org/10.1523/JNEUROSCI.2642-08.2008)

Chehab FF, Lim ME \& Lu R 1996 Correction of the sterility defect in homozygous obese female mice by treatment with the human recombinant leptin. Nature Genetics 12 318-320. (https://doi. org/10.1038/ng0396-318)

Chehab FF, Mounzih K, Lu R \& Lim ME 1997 Early onset of reproductive function in normal female mice treated with leptin. Science $\mathbf{2 7 5}$ 88-90. (https://doi.org/10.1126/science.275.5296.88)

Cheung CC, Thornton JE, Kuijper JL, Weigle DS, Clifton DK \& Steiner RA 1997 Leptin is a metabolic gate for the onset of puberty in the female rat. Endocrinology 138 855-858. (https://doi.org/10.1210/ endo.138.2.5054)

Cheung CC, Kurrasch DM, Liang JK \& Ingraham HA 2013 Genetic labeling of steroidogenic factor-1 (SF-1) neurons in mice reveals ventromedial nucleus of the hypothalamus (VMH) circuitry beginning at neurogenesis and development of a separate non-SF-1 neuronal cluster in the ventrolateral VMH. Journal of Comparative Neurology 521 1268-1288. (https://doi.org/10.1002/cne.23226)

Cicchetti D \& Rogosch FA 2001 Diverse patterns of neuroendocrine activity in maltreated children. Development and Psychopathology 13 677-693. (https://doi.org/10.1017/S0954579401003145)

Clark AM, Ledger W, Galletly C, Tomlinson L, Blaney F, Wang X \& Norman RJ 1995 Weight loss results in significant improvement in pregnancy and ovulation rates in anovulatory obese women. Human Reproduction 10 2705-2712. (https://doi.org/10.1093/oxfordjournals. humrep.a135772)

Clarke MA, Stefanidis A \& Spencer SJ 2012 Postnatal overfeeding leads to obesity and exacerbated febrile responses to lipopolysaccharide throughout life. Journal of Neuroendocrinology 24 511-524. (https://doi. org/10.1111/j.1365-2826.2011.02269.x)

Clarkson J \& Herbison AE 2006 Postnatal development of kisspeptin neurons in mouse hypothalamus; sexual dimorphism and projections to gonadotropin-releasing hormone neurons. Endocrinology 147 5817-5825. (https://doi.org/10.1210/en.2006-0787)

Clarkson J, d'Anglemont de Tassigny X, Colledge WH, Caraty A \& Herbison AE 2009 Distribution of kisspeptin neurones in the adult female mouse brain. Journal of Neuroendocrinology 21 673-682. (https://doi.org/10.1111/j.1365-2826.2009.01892.x)

Clegg DJ, Brown LM, Woods SC \& Benoit SC 2006 Gonadal hormones determine sensitivity to central leptin and insulin. Diabetes $\mathbf{5 5}$ 978-987. (https://doi.org/10.2337/diabetes.55.04.06.db05-1339)

Collden G, Balland E, Parkash J, Caron E, Langlet F, Prevot V \& Bouret SG 2015 Neonatal overnutrition causes early alterations in the central response to peripheral ghrelin. Molecular Metabolism 4 15-24. (https:// doi.org/10.1016/j.molmet.2014.10.003)

Connor KL, Vickers MH, Beltrand J, Meaney MJ \& Sloboda DM 2012 Nature, nurture or nutrition? Impact of maternal nutrition on maternal care, offspring development and reproductive function. Journal of Physiology 590 2167-2180. (https://doi.org/10.1113/ jphysiol.2011.223305)

Cottrell EC, Cripps RL, Duncan JS, Barrett P, Mercer JG, Herwig A \& Ozanne SE 2009 Developmental changes in hypothalamic leptin receptor: relationship with the postnatal leptin surge and energy (c) 2018 Society for Endocrinology Published by Bioscientifica Ltd. Printed in Great Britain 
balance neuropeptides in the postnatal rat. American Journal of Physiology: Regulatory, Integrative and Comparative Physiology 296 R631-R639. (https://doi.org/10.1152/ajpregu.90690.2008)

Cowley MA, Pronchuk N, Fan W, Dinulescu DM, Colmers WF \& Cone RD 1999 Integration of NPY, AGRP, and melanocortin signals in the hypothalamic paraventricular nucleus: evidence of a cellular basis for the adipostat. Neuron 24 155-163. (https://doi.org/10.1016/S08966273(00)80829-6)

Croizier S, Amiot C, Chen X, Presse F, Nahon JL, Wu JY, Fellmann D \& Risold PY 2011 Development of posterior hypothalamic neurons enlightens a switch in the prosencephalic basic plan. PLOS ONE 6 e28574. (https://doi.org/10.1371/journal.pone.0028574)

Delahaye F, Breton C, Risold PY, Enache M, Dutriez-Casteloot I, Laborie C, Lesage J \& Vieau D 2008 Maternal perinatal undernutrition drastically reduces postnatal leptin surge and affects the development of arcuate nucleus proopiomelanocortin neurons in neonatal male rat pups. Endocrinology 149 470-475. (https://doi.org/10.1210/en.2007-1263)

Di Sante G, Wang L, Wang C, Jiao X, Casimiro MC, Chen K, Pestell TG, Yaman I, Di Rocco A, Sun X, et al. 2015 Sirt1-deficient mice have hypogonadotropic hypogonadism due to defective GnRH neuronal migration. Molecular Endocrinology 29 200-212. (https://doi. org/10.1210/me.2014-1228)

Donato J Jr, Cravo RM, Frazão R, Gautron L, Scott MM, Lachey J, Castro IA, Margatho LO, Lee S, Lee C, et al. 2011 Leptin's effect on puberty in mice is relayed by the ventral premammillary nucleus and does not require signaling in Kiss1 neurons. Journal of Clinical Investigation 121 355-368. (https://doi.org/10.1172/JCI45106)

Eghbal-Ahmadi M, Hatalski CG, Avishai-Eliner S \& Baram TZ 1997 Corticotropin releasing factor receptor type II (CRF2) messenger ribonucleic acid levels in the hypothalamic ventromedial nucleus of the infant rat are reduced by maternal deprivation. Endocrinology 138 5048-5051. (https://doi.org/10.1210/endo.138.11.5647)

El-Eshmawy MM, Abdel Aal IA \& El Hawary AK 2010 Association of ghrelin and leptin with reproductive hormones in constitutional delay of growth and puberty. Reproductive Biology and Endocrinology $\mathbf{8}$ 153. (https://doi.org/10.1186/1477-7827-8-153)

Engelbregt MJ, Houdijk ME, Popp-Snijders C \& Delemarre-van de Waal HA 2000 The effects of intra-uterine growth retardation and postnatal undernutrition on onset of puberty in male and female rats. Pediatric Research 48 803-807. (https://doi.org/10.1203/00006450200012000-00017)

Farooqi IS, Jebb SA, Langmack G, Lawrence E, Cheetham CH, Prentice AM, Hughes IA, McCamish MA \& O'Rahilly S 1999 Effects of recombinant leptin therapy in a child with congenital leptin deficiency. New England Journal of Medicine 341 879-884. (https://doi. org/10.1056/NEJM199909163411204)

Farooqi IS, Matarese G, Lord GM, Keogh JM, Lawrence E, Agwu C, Sanna V, Jebb SA, Perna F, Fontana S, et al. 2002 Beneficial effects of leptin on obesity, T cell hyporesponsiveness, and neuroendocrine/ metabolic dysfunction of human congenital leptin deficiency. Journal of Clinical Investigation 110 1093-1103. (https://doi.org/10.1172/ JCI0215693)

Fernandez-Fernandez R, Tena-Sempere M, Aguilar E \& Pinilla L 2004 Ghrelin effects on gonadotropin secretion in male and female rats. Neuroscience Letters 362 103-117. (https://doi.org/10.1016/j. neulet.2004.03.003)

Fernandez-Fernandez R, Tena-Sempere M, Navarro VM, Barreiro ML, Castellano JM, Aguilar E \& Pinilla L 2005 Effects of ghrelin upon gonadotropin-releasing hormone and gonadotropin secretion in adult female rats: in vivo and in vitro studies. Neuroendocrinology $\mathbf{8 2}$ 245-255. (https://doi.org/10.1159/000092753)

Fernandez-Fernandez R, Tena-Sempere M, Roa J, Castellano JM, Navarro VM, Aguilar E \& Pinilla L 2007 Direct stimulatory effect of ghrelin on pituitary release of LH through a nitric oxide-dependent mechanism that is modulated by estrogen. Reproduction 133 1223-1232. (https://doi.org/10.1530/REP-06-0227)
Fernandez-Galaz MC, Naftolin F \& Garcia-Segura LM 1999 Phasic synaptic remodeling of the rat arcuate nucleus during the estrous cycle depends on insulin-like growth factor-I receptor activation. Journal of Neuroscience Research 55 286-292. (https://doi.org/10.1002/ (SICI) 1097-4547(19990201)55:3<286::AID-JNR3>3.0.CO;2-4)

Forbes S, Li XF, Kinsey-Jones J \& O’Byrne K 2009 Effects of ghrelin on Kisspeptin mRNA expression in the hypothalamic medial preoptic area and pulsatile luteinising hormone secretion in the female rat. Neuroscience Letters 460 143-147. (https://doi.org/10.1016/j. neulet.2009.05.060)

Franceschini I \& Desroziers E 2013 Development and aging of the kisspeptin-GPR54 system in the mammalian brain: what are the impacts on female reproductive function? Frontiers in Endocrinology 4 22. (https://doi.org/10.3389/fendo.2013.00022)

Frazao R, Dungan Lemko HM, da Silva RP, Ratra DV, Lee CE, Williams KW, Zigman JM \& Elias CF 2014 Estradiol modulates Kiss1 neuronal response to ghrelin. American Journal of Physiology: Endocrinology and Metabolism 306 E606-E614. (https://doi. org/10.1152/ajpendo.00211.2013)

Gao Q, Mezei G, Nie Y, Rao Y, Choi CS, Bechmann I, Leranth C, ToranAllerand D, Priest CA, Roberts JL, et al. 2007 Anorectic estrogen mimics leptin's effect on the rewiring of melanocortin cells and Stat3 signaling in obese animals. Nature Medicine 13 89-94. (https://doi. org/10.1038/nm1525)

Giacobini P 2015 Shaping the reproductive system: role of semaphorins in gonadotropin-releasing hormone development and function. Neuroendocrinology 102 200-215. (https://doi.org/10.1159/000431021)

Grayson BE, Allen SE, Billes SK, Williams SM, Smith MS \& Grove KL 2006 Prenatal development of hypothalamic neuropeptide systems in the nonhuman primate. Neuroscience 143 975-986. (https://doi. org/10.1016/j.neuroscience.2006.08.055)

Guerriero KA, Keen KL \& Terasawa E 2012 Developmental increase in kisspeptin-54 release in vivo is independent of the pubertal increase in estradiol in female rhesus monkeys (Macaca mulatta). Endocrinology 153 1887-1897. (https://doi.org/10.1210/en.2011-1701)

Gunnar MR, Morison SJ, Chisholm K \& Schuder M 2001 Salivary cortisol levels in children adopted from romanian orphanages. Development and Psychopathology 13 611-628. (https://doi.org/10.1017/ S095457940100311X)

Guzman C, Cabrera R, Cárdenas M, Larrea F, Nathanielsz PW \& Zambrano E 2006 Protein restriction during fetal and neonatal development in the rat alters reproductive function and accelerates reproductive ageing in female progeny. Journal of Physiology $\mathbf{5 7 2}$ 97-108. (https://doi.org/10.1113/jphysiol.2005.103903)

Han SK, Gottsch ML, Lee KJ, Popa SM, Smith JT, Jakawich SK, Clifton DK, Steiner RA \& Herbison AE 2005 Activation of gonadotropin-releasing hormone neurons by kisspeptin as a neuroendocrine switch for the onset of puberty. Journal of Neuroscience 25 11349-11356. (https://doi. org/10.1523/JNEUROSCI.3328-05.2005)

Herman JP, Ostrander MM, Mueller NK \& Figueiredo H 2005 Limbic system mechanisms of stress regulation: hypothalamo-pituitaryadrenocortical axis. Progress in Neuro-Psychopharmacology and Biological Psychiatry 29 1201-1213. (https://doi.org/10.1016/j. pnpbp.2005.08.006)

Herman JP, McKlveen JM, Ghosal S, Kopp B, Wulsin A, Makinson R, Scheimann J \& Myers B 2016 Regulation of the hypothalamicpituitary-adrenocortical stress response. Comprehensive Physiology 6 603-621. (https://doi.org/10.1002/cphy.c150015)

Horvath TL, Sarman B, García-Cáceres C, Enriori PJ, Sotonyi P, Shanabrough M, Borok E, Argente J, Chowen JA, Perez-Tilve D, et al. 2010 Synaptic input organization of the melanocortin system predicts diet-induced hypothalamic reactive gliosis and obesity. PNAS $\mathbf{1 0 7}$ 14875-14880. (https://doi.org/10.1073/pnas.1004282107)

Howard SR, Guasti L, Ruiz-Babot G, Mancini A, David A, Storr HL, Metherell LA, Sternberg MJ, Cabrera CP, Warren HR, et al. 2016 IGSF10 mutations dysregulate gonadotropin-releasing hormone 
neuronal migration resulting in delayed puberty. $E M B O$ Molecular Medicine 8 626-642. (https://doi.org/10.15252/emmm.201606250)

Hung AJ, Stanbury MG, Shanabrough M, Horvath TL, Garcia-Segura LM \& Naftolin F 2003 Estrogen, synaptic plasticity and hypothalamic reproductive aging. Experimental Gerontology 38 53-59. (https://doi. org/10.1016/S0531-5565(02)00183-3)

Hutchins BI, Kotan LD, Taylor-Burds C, Ozkan Y, Cheng PJ, Gurbuz F, Tiong JD, Mengen E, Yuksel B, Topaloglu AK, et al. 2016 CCDC141 mutation identified in anosmic hypogonadotropic hypogonadism (Kallmann syndrome) alters GnRH neuronal migration. Endocrinology 157 1956-1966. (https://doi.org/10.1210/en.2015-1846)

Irwig MS, Fraley GS, Smith JT, Acohido BV, Popa SM, Cunningham MJ, Gottsch ML, Clifton DK \& Steiner RA 2004 Kisspeptin activation of gonadotropin releasing hormone neurons and regulation of KiSS-1 mRNA in the male rat. Neuroendocrinology 80 264-272. (https://doi. org/10.1159/000083140)

Iwasa T, Matsuzaki T, Murakami M, Fujisawa S, Kinouchi R, Gereltsetseg G, Kuwahara A, Yasui T \& Irahara M 2010 Effects of intrauterine undernutrition on hypothalamic Kiss1 expression and the timing of puberty in female rats. Journal of Physiology $\mathbf{5 8 8}$ 821-829. (https://doi.org/10.1113/jphysiol.2009.183558)

Juan De Solis A, Baquero AF, Bennett CM, Grove KL \& Zeltser LM 2016 Postnatal undernutrition delays a key step in the maturation of hypothalamic feeding circuits. Molecular Metabolism 5 198-209. (https://doi.org/10.1016/j.molmet.2016.01.003)

Kamitakahara A, Bouyer K, Wang CH \& Simerly R 2018 A critical period for the trophic actions of leptin on AgRP neurons in the arcuate nucleus of the hypothalamus. Journal of Comparative Neurology $\mathbf{5 2 6}$ 133-145. (https://doi.org/10.1002/cne.24327)

Keen KL, Wegner FH, Bloom SR, Ghatei MA \& Terasawa E 2008 An increase in kisspeptin-54 release occurs with the pubertal increase in luteinizing hormone-releasing hormone-1 release in the stalk-median eminence of female rhesus monkeys in vivo. Endocrinology 149 4151-4157. (https://doi.org/10.1210/en.2008-0231)

Komori T, Morikawa Y, Nanjo K \& Senba E 2006 Induction of brainderived neurotrophic factor by leptin in the ventromedial hypothalamus. Neuroscience 139 1107-1115. (https://doi. org/10.1016/j.neuroscience.2005.12.066)

Kon, IY, Shilina NM, Gmoshinskaya MV \& Ivanushkina TA 2014 The study of breast milk IGF-1, leptin, ghrelin and adiponectin levels as possible reasons of high weight gain in breast-fed infants. Annals of Nutrition and Metabolism 65 317-323. (https://doi. org/10.1159/000367998)

Koutcherov Y, Mai JK, Ashwell KW \& Paxinos G 2002 Organization of human hypothalamus in fetal development. Journal of Comparative Neurology 446 301-324. (https://doi.org/10.1002/cne.10175)

Koutcherov Y, Mai JK \& Paxinos G 2003 Hypothalamus of the human fetus. Journal of Chemical Neuroanatomy 26 253-270. (https://doi. org/10.1016/j.jchemneu.2003.07.002)

Krsmanovic LZ, Hu L, Leung PK, Feng H \& Catt KJ 2009 The hypothalamic GnRH pulse generator: multiple regulatory mechanisms. Trends in Endocrinology and Metabolism 20 402-408. (https://doi.org/10.1016/j.tem.2009.05.002)

Kubo A, Ferrara A, Laurent CA, Windham GC, Greenspan LC, Deardorff J, Hiatt RA, Quesenberry CP \& Kushi LH 2016 Associations between maternal pregravid obesity and gestational diabetes and the timing of pubarche in daughters. American Journal of Epidemiology 184 7-14. (https://doi.org/10.1093/aje/kww006)

Kurian JR, Keen KL, Guerriero KA \& Terasawa E 2012 Tonic control of kisspeptin release in prepubertal monkeys: implications to the mechanism of puberty onset. Endocrinology 153 3331-3336. (https:// doi.org/10.1210/en.2012-1221)

Laing BT, Do K, Matsubara T, Wert DW, Avery MJ, Langdon EM, Zheng D \& Huang H 2016 Voluntary exercise improves hypothalamic and metabolic function in obese mice. Journal of Endocrinology 229 109-122. (https://doi.org/10.1530/JOE-15-0510)
Lajud N, Roque A, Cajero M, Gutiérrez-Ospina G \& Torner L 2012 Periodic maternal separation decreases hippocampal neurogenesis without affecting basal corticosterone during the stress hyporesponsive period, but alters HPA axis and coping behavior in adulthood. Psychoneuroendocrinology 37 410-420. (https://doi. org/10.1016/j.psyneuen.2011.07.011)

Laurent HK, Gilliam KS, Wright DB \& Fisher PA 2015 Child anxiety symptoms related to longitudinal cortisol trajectories and acute stress responses: evidence of developmental stress sensitization. Journal of Abnormal Psychology 124 68-79. (https://doi.org/10.1037/ abn0000009)

Lee DA, Bedont JL, Pak T, Wang H, Song J, Miranda-Angulo A, Takiar V, Charubhumi V, Balordi F, Takebayashi H, et al. 2012 Tanycytes of the hypothalamic median eminence form a diet-responsive neurogenic niche. Nature Neuroscience 15 700-702. (https://doi.org/10.1038/ nn.3079)

Leonhardt M, Lesage J, Croix D, Dutriez-Casteloot I, Beauvillain JC \& Dupouy JP 2003 Effects of perinatal maternal food restriction on pituitary-gonadal axis and plasma leptin level in rat pup at birth and weaning and on timing of puberty. Biology of Reproduction $\mathbf{6 8}$ 390-400. (https://doi.org/10.1095/biolreprod.102.003269)

Li J, Tang Y \& Cai D 2012 IKKbeta/NF-kappaB disrupts adult hypothalamic neural stem cells to mediate a neurodegenerative mechanism of dietary obesity and pre-diabetes. Nature Cell Biology $\mathbf{1 4}$ 999-1012. (https://doi.org/10.1038/ncb2562)

Li G, Zhang W, Baker MS, Laritsky E, Mattan-Hung N, Yu D, KundeRamamoorthy G, Simerly RB, Chen R, Shen L, et al. 2014 Major epigenetic development distinguishing neuronal and non-neuronal cells occurs postnatally in the murine hypothalamus. Human Molecular Genetics 23 1579-1590. (https://doi.org/10.1093/hmg/ddt548)

Liao GY, Bouyer K, Kamitakahara A, Sahibzada N, Wang CH, Rutlin M, Simerly RB \& Xu B 2015 Brain-derived neurotrophic factor is required for axonal growth of selective groups of neurons in the arcuate nucleus. Molecular Metabolism 4 471-482. (https://doi.org/10.1016/j. molmet.2015.03.003)

Lopez M, Seoane LM, Tovar S, García MC, Nogueiras R, Diéguez C \& Señarís RM 2005 A possible role of neuropeptide Y, agouti-related protein and leptin receptor isoforms in hypothalamic programming by perinatal feeding in the rat. Diabetologia 48 140-148. (https://doi. org/10.1007/s00125-004-1596-z)

Louis GW, Greenwald-Yarnell M, Phillips R, Coolen LM, Lehman MN \& Myers MG Jr 2011 Molecular mapping of the neural pathways linking leptin to the neuroendocrine reproductive axis. Endocrinology 152 2302-2310. (https://doi.org/10.1210/en.2011-0096)

Low VF, Fiorini Z, Fisher L \& Jasoni CL 2012 Netrin-1 stimulates developing GnRH neurons to extend neurites to the median eminence in a calcium- dependent manner. PLOS ONE 7 e46999. (https://doi.org/10.1371/journal.pone.0046999)

Lu XY, Barsh GS, Akil H \& Watson SJ 2003 Interaction between alphamelanocyte-stimulating hormone and corticotropin-releasing hormone in the regulation of feeding and hypothalamo-pituitaryadrenal responses. Journal of Neuroscience 23 7863-7872.

Macri S, Pasquali P, Bonsignore LT, Pieretti S, Cirulli F, Chiarotti F \& Laviola G 2007 Moderate neonatal stress decreases within-group variation in behavioral, immune and HPA responses in adult mice. PLoS ONE 2 e1015. (https://doi.org/10.1371/journal.pone.0001015)

Martini AC, Fernández-Fernández R, Tovar S, Navarro VM, Vigo E, Vazquez MJ, Davies JS, Thompson NM, Aguilar E, Pinilla L, et al. 2006 Comparative analysis of the effects of ghrelin and unacylated ghrelin on luteinizing hormone secretion in male rats. Endocrinology $\mathbf{1 4 7}$ 2374-2382. (https://doi.org/10.1210/en.2005-1422)

Matkovic V, Ilich JZ, Skugor M, Badenhop NE, Goel P, Clairmont A, Klisovic D, Nahhas RW \& Landoll JD 1997 Leptin is inversely related to age at menarche in human females. Journal of Clinical Endocrinology and Metabolism 82 3239-3245. (https://doi.org/10.1210/ jcem.82.10.4280) 
Matsumoto A \& Arai Y 1976 Developmental changes in synaptic formation in the hypothalamic arcuate nucleus of female rats. Cell and Tissue Research 169 143-156.

McIntosh J, Anisman H \& Merali Z 1999 Short- and long-periods of neonatal maternal separation differentially affect anxiety and feeding in adult rats: gender-dependent effects. Brain Research Developmental Brain Research 113 97-106. (https://doi.org/10.1016/S0165-3806(99)00005-X)

Melnick I, Pronchuk N, Cowley MA, Grove KL \& Colmers WF 2007 Developmental switch in neuropeptide $\mathrm{Y}$ and melanocortin effects in the paraventricular nucleus of the hypothalamus. Neuron 56 1103-1115. (https://doi.org/10.1016/j.neuron.2007.10.034)

Messager S, Chatzidaki EE, Ma D, Hendrick AG, Zahn D, Dixon J, Thresher RR, Malinge I, Lomet D, Carlton MB, et al. 2005 Kisspeptin directly stimulates gonadotropin-releasing hormone release via $\mathrm{G}$ protein-coupled receptor 54. PNAS 102 1761-1766. (https://doi. org/10.1073/pnas.0409330102)

Migaud M, Butruille L, Duittoz A, Pillon D \& Batailler M 2016 Adult neurogenesis and reproductive functions in mammals. Theriogenology 86 313-323. (https://doi.org/10.1016/j.theriogenology.2016.04.044)

Mistry AM, Swick A \& Romsos DR 1999 Leptin alters metabolic rates before acquisition of its anorectic effect in developing neonatal mice. American Journal of Physiology 277 R742-R747.

Mohr MA, DonCarlos LL \& Sisk CL 2017 Inhibiting production of new brain cells during puberty or adulthood blunts the hormonally induced surge of luteinizing hormone in female rats. eNeuro 4 [epub]. (https://doi.org/10.1523/ENEURO.0133-17.2017)

Moore AM \& Campbell RE 2017 Polycystic ovary syndrome: understanding the role of the brain. Frontiers in Neuroendocrinology 46 1-14. (https://doi.org/10.1016/j.yfrne.2017.05.002)

Morley-Fletcher S, Rea M, Maccari S \& Laviola G 2003 Environmental enrichment during adolescence reverses the effects of prenatal stress on play behaviour and HPA axis reactivity in rats. European Journal of Neuroscience 18 3367-3374. (https://doi.org/10.1111/j.14609568.2003.03070.x)

Naftolin F, Mor G, Horvath TL, Luquin S, Fajer AB, Kohen F \& GarciaSegura LM 1996 Synaptic remodeling in the arcuate nucleus during the estrous cycle is induced by estrogen and precedes the preovulatory gonadotropin surge. Endocrinology 137 5576-5580. (https://doi.org/10.1210/endo.137.12.8940386)

Navarro VM, Castellano JM, Fernández-Fernández R, Barreiro ML, Roa J, Sanchez-Criado JE, Aguilar E, Dieguez C, Pinilla L \& Tena-Sempere M 2004 Developmental and hormonally regulated messenger ribonucleic acid expression of KiSS-1 and its putative receptor, GPR54, in rat hypothalamus and potent luteinizing hormone-releasing activity of KiSS-1 peptide. Endocrinology 145 4565-4574. (https://doi. org/10.1210/en.2004-0413)

Ng PC, Lee CH, Lam CW, Chan IH, Wong E \& Fok TF 2005 Ghrelin in preterm and term newborns: relation to anthropometry, leptin and insulin. Clinical Endocrinology 63 217-222. (https://doi.org/10.1111/ j.1365-2265.2005.02328.x)

Ohkura S, Uenoyama Y, Yamada S, Homma T, Takase K, Inoue N, Maeda K \& Tsukamura H 2009 Physiological role of metastin/ kisspeptin in regulating gonadotropin-releasing hormone $(\mathrm{GnRH})$ secretion in female rats. Peptides 30 49-56. (https://doi.org/10.1016/j. peptides.2008.08.004)

Olmos G, Naftolin F, Perez J, Tranque PA \& Garcia-Segura LM 1989 Synaptic remodeling in the rat arcuate nucleus during the estrous cycle. Neuroscience 32 663-667. (https://doi.org/10.1016/03064522(89)90288-1)

Parker KJ, Buckmaster CL, Justus KR, Schatzberg AF \& Lyons DM 2005 Mild early life stress enhances prefrontal-dependent response inhibition in monkeys. Biological Psychiatry 57 848-855. (https://doi. org/10.1016/j.biopsych.2004.12.024)

Pearson CA \& Placzek M 2013 Development of the medial hypothalamus: forming a functional hypothalamic-neurohypophyseal interface.
Current Topics in Developmental Biology 106 49-88. (https://doi. org/10.1016/B978-0-12-416021-7.00002-X)

Pinto S, Roseberry AG, Liu H, Diano S, Shanabrough M, Cai X, Friedman JM \& Horvath TL 2004 Rapid rewiring of arcuate nucleus feeding circuits by leptin. Science 304 110-115. (https://doi. org/10.1126/science.1089459)

Plagemann A, Heidrich I, Götz F, Rohde W \& Dörner G 1992 Lifelong enhanced diabetes susceptibility and obesity after temporary intrahypothalamic hyperinsulinism during brain organization. Experimental and Clinical Endocrinology 99 91-95. (https://doi. org/10.1055/s-0029-1211143)

Plagemann A, Harder T, Rake A, Janert U, Melchior K, Rohde W \& Dörner G 1999 Morphological alterations of hypothalamic nuclei due to intrahypothalamic hyperinsulinism in newborn rats. International Journal of Developmental Neuroscience 17 37-44. (https://doi. org/10.1016/S0736-5748(98)00064-1)

Plagemann A, Harder T, Brunn M, Harder A, Roepke K, WittrockStaar M, Ziska T, Schellong K, Rodekamp E, Melchior K, et al. 2009 Hypothalamic proopiomelanocortin promoter methylation becomes altered by early overfeeding: an epigenetic model of obesity and the metabolic syndrome. Journal of Physiology 587 4963-4976. (https:// doi.org/10.1113/jphysiol.2009.176156)

Plant TM 2015 Neuroendocrine control of the onset of puberty. Frontiers in Neuroendocrinology 38 73-88. (https://doi.org/10.1016/j. yfrne.2015.04.002)

Plant TM \& Barker-Gibb ML 2004 Neurobiological mechanisms of puberty in higher primates. Human Reproduction Update 10 67-77. (https://doi.org/10.1093/humupd/dmh001)

Plant TM \& Witchel SF 2006 Puberty in nonhuman primates and humans. In Knobil and Neill's Physiology of Reproduction (Third Edition), ch 40, pp 2177-2230. Ed JD Neill. St Louis, MI, USA: Academic Press.

Rae MT, Kyle CE, Miller DW, Hammond AJ, Brooks AN \& Rhind SM 2002 The effects of undernutrition, in utero, on reproductive function in adult male and female sheep. Animal Reproduction Science 72 63-71. (https://doi.org/10.1016/S0378-4320(02)00068-4)

Rao R 2015 Hypothalamic-pituitary-adrenal axis programming after recurrent hypoglycemia during development. Journal of Clinical Medicine 4 1729-1740. (https://doi.org/10.3390/jcm4091729)

Rosenfeld P, Ekstrand J, Olson E, Suchecki D \& Levine S 1993 Maternal regulation of adrenocortical activity in the infant rat: effects of feeding. Developmental Psychobiology 26 261-277. (https://doi. org/10.1002/dev.420260504)

Rots NY, de Jong J, Workel JO, Levine S, Cools AR \& De Kloet ER 1996 Neonatal maternally deprived rats have as adults elevated basal pituitary-adrenal activity and enhanced susceptibility to apomorphine. Journal of Neuroendocrinology 8 501-506. (https://doi. org/10.1046/j.1365-2826.1996.04843.x)

Sanchez-Garrido MA \& Tena-Sempere M 2013 Metabolic control of puberty: roles of leptin and kisspeptins. Hormones and Behavior 64 187-194. (https://doi.org/10.1016/j.yhbeh.2013.01.014)

Sanders TR, Kim DW, Glendining KA \& Jasoni CL 2014 Maternal obesity and IL-6 lead to aberrant developmental gene expression and deregulated neurite growth in the fetal arcuate nucleus. Endocrinology 155 2566-2577. (https://doi.org/10.1210/en.2013-1968)

Sanders TR, Glendining KA \& Jasoni CL 2017 Obesity during pregnancy in the mouse alters the Netrin-1 responsiveness of fetal arcuate nucleus NPY neurons. Journal of Neuroendocrinology 29 1-10. (https:// doi.org/10.1111/jne.12556)

Schmidt M, Enthoven L, van Woezik JH, Levine S, de Kloet ER \& Oitzl MS 2004 The dynamics of the hypothalamic-pituitary-adrenal axis during maternal deprivation. Journal of Neuroendocrinology 16 52-57. (https:// doi.org/10.1111/j.1365-2826.2004.01123.x)

Schmidt MV, Levine S, Alam S, Harbich D, Sterlemann V, Ganea K, de Kloet ER, Holsboer F \& Müller MB 2006 Metabolic signals modulate hypothalamic-pituitary-adrenal axis activation during maternal
๑) 2018 Society for Endocrinology Published by Bioscientifica Ltd. Printed in Great Britain 
separation of the neonatal mouse. Journal of Neuroendocrinology $\mathbf{1 8}$ 865-874. (https://doi.org/10.1111/j.1365-2826.2006.01482.x)

Sen TA, Şimşek DK, Darcan S \& Çoker M 2010 Ghrelin levels in children with constitutional delay of growth and puberty. Journal of Clinical Research in Pediatric Endocrinology 2 117-121. (https://doi.org/10.4274/ jcrpe.v2i3.117)

Sengupta P 2013 The laboratory rat: relating its age with human's. International Journal of Preventive Medicine 4 624-630.

Shahab M, Mastronardi C, Seminara SB, Crowley WF, Ojeda SR \& Plant TM 2005 Increased hypothalamic GPR54 signaling: a potential mechanism for initiation of puberty in primates. PNAS $\mathbf{1 0 2}$ 2129-2134. (https://doi.org/10.1073/pnas.0409822102)

Shimamura K, Hartigan DJ, Martinez S, Puelles L \& Rubenstein JL 1995 Longitudinal organization of the anterior neural plate and neural tube. Development 121 3923-3933.

Sloboda DM, Howie GJ, Pleasants A, Gluckman PD \& Vickers MH 2009 Pre- and postnatal nutritional histories influence reproductive maturation and ovarian function in the rat. PLOS ONE $\mathbf{4}$ e6744. (https://doi.org/10.1371/journal.pone.0006744)

Smith JT \& Spencer SJ 2012 Preweaning over- and underfeeding alters onset of puberty in the rat without affecting kisspeptin. Biology of Reproduction 86 1-8. (https://doi.org/10.1095/biolreprod.111.097758)

Smith JT, Reichenbach A, Lemus M, Mani BK, Zigman JM \& Andrews ZB 2013 An eGFP-expressing subpopulation of growth hormone secretagogue receptor cells are distinct from kisspeptin, tyrosine hydroxylase, and RFamide-related peptide neurons in mice. Peptides 47 45-53. (https://doi.org/10.1016/j.peptides.2013.06.012)

Sominsky L, Ziko I, Soch A, Smith JT \& Spencer SJ 2016 Neonatal overfeeding induces early decline of the ovarian reserve: implications for the role of leptin. Molecular and Cellular Endocrinology 431 24-35. (https://doi.org/10.1016/j.mce.2016.05.001)

Sominsky L, Ziko I, Nguyen TX, Andrews ZB \& Spencer SJ 2017a Early life disruption to the ghrelin system with over-eating is resolved in adulthood in male rats. Neuropharmacology 113 21-30. (https://doi. org/10.1016/j.neuropharm.2016.09.023)

Sominsky L, Ziko I, Nguyen TX, Quach J \& Spencer SJ 2017 b Hypothalamic effects of neonatal diet: reversible and only partially leptin dependent. Journal of Endocrinology 234 41-56. (https://doi. org/10.1530/JOE-16-0631)

Soriano-Guillen L, Barrios V, Campos-Barros A \& Argente J 2004a Ghrelin levels in obesity and anorexia nervosa: effect of weight reduction or recuperation. Journal of Pediatrics 144 36-42. (https://doi. org/10.1016/j.jpeds.2003.10.036)

Soriano-Guillen L, Barrios V, Chowen JA, Sánchez I, Vila S, Quero J \& Argente J 2004b Ghrelin levels from fetal life through early adulthood: relationship with endocrine and metabolic and anthropometric measures. Journal of Pediatrics 144 30-35. (https://doi. org/10.1016/j.jpeds.2003.08.050)

Spencer SJ 2013 Perinatal programming of neuroendocrine mechanisms connecting feeding behavior and stress. Frontiers in Neuroscience 7109. (https://doi.org/10.3389/fnins.2013.00144)

Spencer SJ \& Tilbrook A 2009 Neonatal overfeeding alters adult anxiety and stress responsiveness. Psychoneuroendocrinology 34 1133-1143. (https://doi.org/10.1016/j.psyneuen.2009.02.013)

Steculorum SM, Collden G, Coupe B, Croizier S, Lockie S, Andrews ZB, Jarosch F, Klussmann S \& Bouret SG 2015 Neonatal ghrelin programs development of hypothalamic feeding circuits. Journal of Clinical Investigation 125 846-858. (https://doi.org/10.1172/JCI73688)

Stefanidis A \& Spencer SJ 2012 Effects of neonatal overfeeding on juvenile and adult feeding and energy expenditure in the rat. PLoS ONE 7 e52130. (https://doi.org/10.1371/journal.pone.0052130)

Stettler N, Stallings VA, Troxel AB, Zhao J, Schinnar R, Nelson SE, Ziegler EE \& Strom BL 2005 Weight gain in the first week of life and overweight in adulthood: a cohort study of European American subjects fed infant formula. Circulation 111 1897-1903. (https://doi. org/10.1161/01.CIR.0000161797.67671.A7)
Takase K, Uenoyama Y, Inoue N, Matsui H, Yamada S, Shimizu M, Homma T, Tomikawa J, Kanda S, Matsumoto H, et al. 2009 Possible role of oestrogen in pubertal increase of Kiss1/kisspeptin expression in discrete hypothalamic areas of female rats. Journal of Neuroendocrinology 21 527-537. (https://doi.org/10.1111/j.13652826.2009.01868.x)

Takumi K, Iijima N \& Ozawa H 2011 Developmental changes in the expression of kisspeptin mRNA in rat hypothalamus. Journal of Molecular Neuroscience 43 138-145. (https://doi.org/10.1007/s12031010-9430-1)

Terasawa E 2005 Role of GABA in the mechanism of the onset of puberty in non-human primates. International Review of Neurobiology $\mathbf{7 1}$ 113-129.

Terasawa E \& Kurian JR 2012 Neuroendocrine mechanism of puberty. In Handbook of Neuroendocrinology, ch 19, pp 433-484. Eds DW Pfaff \& JE Levine. San Diego, CA, USA: Academic Press. (https://doi. org/10.1016/B978-0-12-375097-6.10019-8)

Terasawa E, Guerriero KA \& Plant TM 2013 Kisspeptin and puberty in mammals. Advances in Experimental Medicine and Biology 784 253-273. (https://doi.org/10.1007/978-1-4614-6199-9_12)

Ubuka T, Morgan K, Pawson AJ, Osugi T, Chowdhury VS, Minakata H, Tsutsui K, Millar RP \& Bentley GE 2009 Identification of human GnIH homologs, RFRP-1 and RFRP-3, and the cognate receptor, GPR147 in the human hypothalamic pituitary axis. PLoS ONE $\mathbf{4}$ e8400. (https:// doi.org/10.1371/journal.pone.0008400)

Ukena K, Iwakoshi E, Minakata H \& Tsutsui K 2002 A novel rat hypothalamic RFamide-related peptide identified by immunoaffinity chromatography and mass spectrometry. FEBS Letters 512 255-258. (https://doi.org/10.1016/S0014-5793(02)02275-5)

Valleau JC \& Sullivan EL 2014 The impact of leptin on perinatal development and psychopathology. Journal of Chemical Neuroanatomy 61-62 221-232. (https://doi.org/10.1016/j.jchemneu.2014.05.001)

van Oers HJ, de Kloet ER, Whelan T \& Levine S 1998 Maternal deprivation effect on the infant's neural stress markers is reversed by tactile stimulation and feeding but not by suppressing corticosterone. Journal of Neuroscience 18 10171-10179.

Vickers MH, Gluckman PD, Coveny AH, Hofman PL, Cutfield WS, Gertler A, Breier BH \& Harris M 2005 Neonatal leptin treatment reverses developmental programming. Endocrinology 146 4211-4216. (https://doi.org/10.1210/en.2005-0581)

Vogt MC, Paeger L, Hess S, Steculorum SM, Awazawa M, Hampel B, Neupert S, Nicholls HT, Mauer J, Hausen AC, et al. 2014 Neonatal insulin action impairs hypothalamic neurocircuit formation in response to maternal high-fat feeding. Cell 156 495-509. (https://doi. org/10.1016/j.cell.2014.01.008)

Vukojevic V, Kolassa IT, Fastenrath M, Gschwind L, Spalek K, Milnik A, Heck A, Vogler C, Wilker S, Demougin P, et al. 2014 Epigenetic modification of the glucocorticoid receptor gene is linked to traumatic memory and post-traumatic stress disorder risk in genocide survivors. Journal of Neuroscience 34 10274-10284. (https://doi. org/10.1523/JNEUROSCI.1526-14.2014)

Walker CD, Tankosic P, Tilders FJ \& Burlet A 1997 Immunotargeted lesions of paraventricular CRF and AVP neurons in developing rats reveal the pattern of maturation of these systems and their functional importance. Journal of Neuroendocrinology 9 25-41. (https://doi. org/10.1046/j.1365-2826.1997.00544.x)

Watanabe G \& Terasawa E 1989 In vivo release of luteinizing hormone releasing hormone increases with puberty in the female rhesus monkey. Endocrinology 125 92-99. (https://doi.org/10.1210/endo-125-1-92)

Waters EM \& Simerly RB 2009 Estrogen induces caspase-dependent cell death during hypothalamic development. Journal of Neuroscience 29 9714-9718. (https://doi.org/10.1523/JNEUROSCI.0135-09.2009)

Watts AG 201560 years of neuroendocrinology: the structure of the neuroendocrine hypothalamus: the neuroanatomical legacy of Geoffrey Harris. Journal of Endocrinology 226 T25-T39. (https://doi. org/10.1530/JOE-15-0157) 
Weaver IC, Cervoni N, Champagne FA, D'Alessio AC, Sharma S, Seckl JR, Dymov S, Szyf M \& Meaney MJ 2004a Epigenetic programming by maternal behavior. Nature Neuroscience 7 847-854. (https://doi. org/10.1038/nn1276)

Weaver IC, Diorio J, Seckl JR, Szyf M \& Meaney MJ 2004b Early environmental regulation of hippocampal glucocorticoid receptor gene expression: characterization of intracellular mediators and potential genomic target sites. Annals of the New York Academy of Sciences 1024 182-212. (https://doi.org/10.1196/annals.1321.099)

Whatmore AJ, Hall CM, Jones J, Westwood M \& Clayton PE 2003 Ghrelin concentrations in healthy children and adolescents. Clinical Endocrinology 59 649-654. (https://doi.org/10.1046/j.13652265.2003.01903.x)

Whitaker RC, Wright JA, Pepe MS, Seidel KD \& Dietz WH 1997 Predicting obesity in young adulthood from childhood and parental obesity. New England Journal of Medicine 337 869-873. (https://doi. org/10.1056/NEJM199709253371301)

Wigger A \& Neumann ID 1999 Periodic maternal deprivation induces gender-dependent alterations in behavioral and neuroendocrine responses to emotional stress in adult rats. Physiology and Behavior 66 293-302. (https://doi.org/10.1016/S0031-9384(98)00300-X)

Witkin JW, Ferin M, Popilskis SJ \& Silverman AJ 1991 Effects of gonadal steroids on the ultrastructure of GnRH neurons in the rhesus monkey: synaptic input and glial apposition. Endocrinology 129 1083-1092. (https://doi.org/10.1210/endo-129-2-1083)

Witzmann SR, Turner JD, Mériaux SB, Meijer OC \& Muller CP 2012 Epigenetic regulation of the glucocorticoid receptor promoter 1(7) in adult rats. Epigenetics 7 1290-1301. (https://doi.org/10.4161/ epi.22363)

Xie Y \& Dorsky RI 2017 Development of the hypothalamus: conservation, modification and innovation. Development 144 1588-1599. (https://doi.org/10.1242/dev.139055)

Yam KY, Naninck EF, Schmidt MV, Lucassen PJ \& Korosi A 2015 Early-life adversity programs emotional functions and the neuroendocrine stress system: the contribution of nutrition, metabolic hormones and epigenetic mechanisms. Stress 18 328-342. (https://doi.org/10.3109/1 0253890.2015.1064890)

Yam KY, Naninck EFG, Abbink MR, la Fleur SE, Schipper L, van den Beukel JC, Grefhorst A, Oosting A, van der Beek EM, Lucassen PJ, et al. $2017 a$ Exposure to chronic early-life stress lastingly alters the adipose tissue, the leptin system and changes the vulnerability to westernstyle diet later in life in mice. Psychoneuroendocrinology 77 186-195. (https://doi.org/10.1016/j.psyneuen.2016.12.012)

Yam KY, Ruigrok SR, Ziko I, De Luca SN, Lucassen PJ, Spencer SJ \& Korosi A 2017b Ghrelin and hypothalamic NPY/AgRP expression in mice are affected by chronic early-life stress exposure in a sexspecific manner. Psychoneuroendocrinology 86 73-77. (https://doi. org/10.1016/j.psyneuen.2017.09.006)

Yehuda R, Flory JD, Bierer LM, Henn-Haase C, Lehrner A, Desarnaud F, Makotkine I, Daskalakis NP, Marmar CR \& Meaney MJ 2015 Lower methylation of glucocorticoid receptor gene promoter $1 \mathrm{~F}$ in peripheral blood of veterans with posttraumatic stress disorder. Biological Psychiatry 77 356-364. (https://doi.org/10.1016/j. biopsych.2014.02.006)

Yeo SH \& Herbison AE 2011 Projections of arcuate nucleus and rostral periventricular kisspeptin neurons in the adult female mouse brain. Endocrinology 152 2387-2399. (https://doi.org/10.1210/en.2011-0164)

Yip SH, Boehm U, Herbison AE \& Campbell RE 2015 Conditional viral tract tracing delineates the projections of the distinct kisspeptin neuron populations to Gonadotropin-Releasing Hormone (GnRH) neurons in the mouse. Endocrinology 156 2582-2594. (https://doi. $\operatorname{org} / 10.1210 /$ en.2015-1131)

Yoshihara T \& Yawaka Y 2008 Repeated immobilization stress in the early postnatal period increases stress response in adult rats. Physiology and Behavior 93 322-326. (https://doi.org/10.1016/j. physbeh.2007.09.004)

Yura S, Itoh H, Sagawa N, Yamamoto H, Masuzaki H, Nakao K, Kawamura M, Takemura M, Kakui K, Ogawa Y, et al. 2005 Role of premature leptin surge in obesity resulting from intrauterine undernutrition. Cell Metabolism 1 371-378. (https://doi.org/10.1016/j. cmet.2005.05.005)

Ziko I, Sominsky L, Nguyen TX, Yam KY, De Luca S, Korosi A \& Spencer SJ 2017 Hyperleptinemia in neonatally overfed female rats does not dysregulate feeding circuitry. Frontiers in Endocrinology 8 287. (https:// doi.org/10.3389/fendo.2017.00287)

Zsarnovszky A, Horvath TL, Garcia-Segura LM, Horvath B \& Naftolin F 2001 Oestrogen-induced changes in the synaptology of the monkey (Cercopithecus aethiops) arcuate nucleus during gonadotropin feedback. Journal of Neuroendocrinology 13 22-28. (https://doi. org/10.1046/j.1365-2826.2001.00602.x)

Received in final form 28 February 2018

Accepted 15 March 2018

Accepted Preprint published online 15 March 2018 http://joe.endocrinology-journals.org

https://doi.org/10.1530/JOE-17-0722
() 2018 Society for Endocrinology Published by Bioscientifica Ltd. Printed in Great Britain 